2020-03-17

\title{
Responses of Intertidal Bacterial Biofilm Communities to Increasing pCO2
}

\author{
Kerfahi, D
}

http://hdl.handle.net/10026.1/15583

10.1007/s10126-020-09958-3

Marine Biotechnology

Springer Science and Business Media LLC

All content in PEARL is protected by copyright law. Author manuscripts are made available in accordance with publisher policies. Please cite only the published version using the details provided on the item record or document. In the absence of an open licence (e.g. Creative Commons), permissions for further reuse of content should be sought from the publisher or author. 
1

2

3

6

7 Responses of intertidal bacterial biofilm communities to increasing $\mathrm{pCO}_{2}$ in

This is the author's accepted manuscript. The final published version of this work (the version of record) is published by Springer Nature in Marine Biotechnology. The manuscript was made available online on the 17 March 2020 at: https:// doi.org/10.1007/s10126-020-09958-3 This work is made available online in accordance with the publisher's policies. Please refer to any applicable terms of use of the publisher.

\section{a naturally acidified system}

9 Dorsaf Kerfahi ${ }^{1}$, Ben Harvey ${ }^{2}$, Sylvain Agostini ${ }^{2}$, Koetsu Kon ${ }^{2}$, Ruiping Huang ${ }^{3}$, Jonathan M. 10 Adams $^{4 *}$, Jason M. Hall-Spencer ${ }^{2,5}$

$11{ }^{1}$ School of Applied Biosciences, College of Agriculture and Life Sciences, Kyungpook National University, Daegu, 41566, Republic of Korea.

${ }^{2}$ Shimoda Marine Research Center, University of Tsukuba, 5-10-1 Shimoda, Shizuoka, Japan.

$14{ }^{3}$ State Key Laboratory of Marine Environmental Science, Xiamen University, Xiamen, Fujian, 361100, China.

${ }^{4}$ School of Geographic and Oceanographic Sciences, Nanjing University, Nanjing 210008, 17 China. United Kingdom.

*Corresponding author: Jonathan M. Adams.

School of Geographic and Oceanographic Sciences, Nanjing University, Nanjing 210008, China. 
E-mail: foundinkualalumpur@yahoo.com 


\section{Abstract}

The effects of ocean acidification on ecosystems remain poorly understood, because it is difficult to simulate the effects of elevated $\mathrm{CO}_{2}$ levels on entire marine communities in controlled laboratory conditions. Natural systems such as $\mathrm{CO}_{2}$ seeps that are enriched in $\mathrm{CO}_{2}$ are being used to help understand the long-term effects of ocean acidification in situ. Here, we compared biofilm bacterial community composition on cobbles/boulders and bedrock along a $\mathrm{CO}_{2}$ gradient in the NW Pacific. Samples sequenced for 16S rRNA showed that different bacterial communities were associated with zones of different seawater $p \mathrm{CO}_{2}$, and were also distinct between the two rocky habitat types. In both habitats, there was increased bacterial diversity in the biofilm communities in acidified conditions. Differences in $p \mathrm{CO}_{2}$ were associated with differences in the relative abundance of major bacterial phyla including Cyanobacteria, Bacteroidetes, Proteobacteria, Planctomycetes, and Verrucomicrobia. However, despite the differences in community composition, there is little sign of changes in the bacterial community that would be functionally significant in terms of nutrient cycling and ecosystem structure. As well as direct seawater $\mathrm{pH}$ effects, it is possible that increased growth of algae and decreased grazing contributed to the observed shift in bacterial community composition at high $\mathrm{CO}_{2}$, as documented at several seep systems worldwide. Given the importance of biofilms to coastal ecology, changes in their composition due to globally rising $p \mathrm{CO}_{2}$ levels requires further investigation to assess the implications for marine ecosystem function. However, the apparent lack of functional shifts in the biofilms despite the $\mathrm{pH}$ change may be a reassuring indicator of stability in shallow oceanic biofilm communities in the future.

Keywords: Bacteria, biodiversity, ocean acidification, rocky shore ecology. 


\section{Introduction}

Bacteria dominate the abundance, diversity and metabolic activities of ocean ecosystems (Azam and Malfatti, 2007). On hard substrates they form attached biofilm communities where they interact in a matrix of extracellular polymeric substances (Decho, 2000; de Carvalho, 2018), which stick the cells to the substrata and protect them against environmental extremes. Marine biofilms rapidly colonise natural and artificial surfaces, and then facilitate the settlement of macroalgae and invertebrates (Lau et al., 2005; Qian et al., 2007). They cycle nutrients and organic matter, and can be a major source of primary productivity in the photic zone, providing an important food resource for higher trophic levels (Thompson et al., 2004; de Carvalho, 2018). Consequently, any changes in biofilm microbial diversity and abundance could have important implications for marine ecosystem structure and function (Weinbauer et al., 2011).

Anthropogenic $\mathrm{CO}_{2}$ emissions are rapidly changing seawater chemistry, in a process called ocean acidification, and a major research priority is to find out how ecosystems will be affected by these changes (Riebesell and Gattuso, 2015). While marine organisms can tolerate large, rapid changes in carbonate chemistry in coastal regions (Wootton et al., 2008), the long-term effects of decreased mean $\mathrm{pH}$ and more frequent episodes of low carbonate saturation and high $p \mathrm{CO}_{2}$ are poorly known. Areas that are naturally exposed to periods of lower $\mathrm{pH}$, lower carbonate saturation and higher $\mathrm{pCO}_{2}$ than those that occurred at preindustrial levels of atmospheric $\mathrm{CO}_{2}$ are helping to further our understanding of the ecosystem effects of ocean acidification (Hall-Spencer et al., 2008; Fabricius et al., 2011; Rastrick et al., 2018). This approach has shown that even in coastal ecosystems, where rapid changes in carbonate chemistry are normal, many calcified organisms are adversely affected when the frequency and duration of low carbonate saturation events increase. Concomitant pulses of high levels of dissolved inorganic carbon benefit certain primary producers, causing 
shifts in their community composition (Porzio et al., 2011; Connell et al., 2013; Cornwall et al., 2017).

Ocean acidification may directly impact microbial diversity and composition, and indirectly affect microbes through links within food webs, for example with non-bacterial competitors and with grazers (Krause et al., 2012; Sunday et al., 2017). Despite the importance of microbial biofilms, few studies have investigated how ocean acidification might affect them (Liu et al., 2010; Kerfahi et al., 2014). Hypothetically, major biogeochemical processes driven by microbes may not be fundamentally different under future elevated $p \mathrm{CO}_{2}$ conditions (Joint et al., 2011) since bacterial communities are able to reorganise themselves in response to environmental perturbations (Tolker-Nielsen and Molin, 2000). Aquarium-based experiments have been used to simulate these future conditions, but it is challenging to predict the responses of microbial communities based on these, as they do not incorporate feedbacks and the many indirect effects that might occur as a result of increased $\mathrm{pCO}_{2}$ in natural systems - for example changes in geochemistry and organism interactions (Das and Mangwani, 2015). For this reason, carbon dioxide seep systems are now being used to investigate the long-term response of microbial communities to ocean acidification (Kerfahi et al., 2014; Morrow et al., 2014; Hassenrück et al., 2015, 2017; O’Brien et al., 2018).

Previous work on biofilm communities at carbon dioxide seeps suggests that their primary productivity will be enhanced by ocean acidification in the photic zone, at least where nutrient levels are sufficient (Lidbury et al., 2012; Johnson et al., 2015) and that there will be broad shifts in their community composition and diversity under increased $p \mathrm{CO}_{2}$ (Kerfahi et al., 2014; Taylor et al., 2014). These biofilm community responses have also been shown in mesocosm-based studies using experimentally elevated $p \mathrm{CO}_{2}$ (Witt et al., 2011) with no evidence of loss of biofilm function due to ocean acidification. 
Natural biofilm communities on rocky shores are highly variable in terms of

community structure and relative abundances, due to abiotic and biotic pressures (Williams et al., 2000), and rocky shore ecology is strongly influenced by shore type e.g. steep cliffs vs boulder fields, or hard vs soft rock substrata (Lewis, 1964). The response of microbial biofilms to the impacts of ocean acidification may differ, depending on habitat type, and may be caused directly by changes in carbonate chemistry, or indirectly due to effects on other organisms (Sunday et al., 2017).

In this study, our aim was to test whether the effects on coastal biofilm bacterial communities of increased seawater $p \mathrm{CO}_{2}$ in the $\mathrm{NW}$ Pacific Ocean are similar to those observed in the Mediterranean Sea (Kerfahi et al., 2014). In Japan, Agostini et al. (2018) recently showed that in complex habitats, at increased levels of $p \mathrm{CO}_{2}$ predominately calcareous organisms were replaced by simplified biofilm-dominated and algal turfdominated habitats. We used the ocean acidification study system established by Agostini et al. (2018) to investigate the bacterial community structure of these biofilms on two types of low rocky shore habitat; cobble/boulder shores, and steep cliff faces. We examined four $p \mathrm{CO}_{2}$ conditions, from pre-Industrial through to present day and projected future levels, to assess impacts of changing ocean chemistry on bacterial communities. We expected to find major changes in biofilm community composition, given the known sensitivity of bacterial communities to $\mathrm{pH}$ (e.g. Lauber et al., 2008; Tripathi et al., 2012), although this type of study has not previously been carried out in the Pacific Ocean.

\section{Materials and methods}

\section{Study site}

Sampling took place on the South coast of Shikine Island, East of the Izu peninsula, Japan in the North West Pacific Ocean $\left(34^{\circ} 32^{\prime} \mathrm{N}, 139^{\circ} 20^{\prime} \mathrm{E}\right)$. The Izu archipelago is a chain 
of islands approximately $150 \mathrm{~km}$ South of Tokyo (Fig. S1) situated at a subtropical-temperate biogeographic boundary due to the influence of the warm North flowing Kuroshio current (Agostini et al., 2018).

\section{Sample collection and DNA extraction}

Samples were collected from six sites along a $\mathrm{pH}$ gradient ranging from 7.2 to 8.3. At each site, six rock chips were randomly collected along a linear $1 \mathrm{~m}$ transect immediately above the low tide line. All samples had the same edaphic parameters, being on boulders (in boulder samples) or cliff faces (in cliff face samples) of the same basaltic lava, on flat faces at vertical westerly orientation and smooth texture. Rock chips were collected in June 2016 using a chisel and placed in individually labelled bags using clean forceps (Fig. S2) and immediately stored at $-20^{\circ} \mathrm{C}$. DNA was extracted from each rockchip sample using the Power Soil DNA extraction kit (MO BIO Laboratories, Carlsbad, CA, USA) following the manufacturer's protocol. The DNA samples were then sent to the Dalhousie University, Canada, for sequencing using an Illumina MiSeq platform.

\section{Seawater chemistry}

Geographical co-ordinates of each sample were taken using a GPS. A multi-sensor (U-5000G, Horiba Ltd, Kyoto Japan) was used to measure seawater pH, temperature, salinity and dissolved oxygen. To measure total alkalinity, $100 \mathrm{ml}$ water samples were collected and then filtered at $0.45 \mu \mathrm{m}$ with cellulose acetate filters (Dismic 045, Advantec Japan). Total alkalinity was measured via titration with $\mathrm{HCl}$ at $0.1 \mathrm{~mol} \mathrm{l}^{-1}$ with a Metrohm titrator (785 DMP titrino) and total alkalinity was calculated by Gran plot from titration point with a $\mathrm{pH}$ between 4.0 and 3.0. Carbonate chemistry parameters: partial $\mathrm{CO}_{2}$ pressure $\left(p \mathrm{CO}_{2}\right)$, Aragonite (Ar) and calcite (Ca) saturation state ( (aragonite, $\Omega$ calcite), and dissolved 
inorganic carbon (DIC) were calculated using the $\mathrm{CO}_{2} \mathrm{SYS}$ software package (Pierrot et al., 2006) using temperature, salinity, $\mathrm{pH}$ (NBS scale) and total alkalinity $\left(\mathrm{A}_{\mathrm{T}}\right)$ with the disassociation constants from Mehrbach et al. (1973), as adjusted by Dickson and Millero (1987), $\mathrm{KSO}_{4}$ using Dickson (1990), and total borate concentrations from Uppström (1974). The carbonate chemistry for the different sites is presented in Table 1.

\section{Sequence analysis}

The sequenced data generated from Miseq sequencing was processed using the Mothur platform (Schloss et al., 2009). The sequences were aligned using Mothur (default settings: kmer searching with 8mers and the Needleman-Wunsch pairwise alignment method). Next, they were aligned against the EzTaxon-aligned reference (Chun et al., 2007), and further filtered to remove gaps. Sequences were de-noised using the 'pre.cluster' command in Mothur implemented using a pseudo-single linkage pre-clustering algorithm from Huse et al. (2010). Putative chimeric sequences were detected and removed via the Chimera Uchime algorithm contained within Mothur (Edgar et al., 2011) in de novo mode, which first splits sequences into groups and then checks each sequence within a group using the more abundant groups as reference. The taxonomic classification was performed using Mothur's version of the RDP Bayesian classifier, using EzTaxon-e database for each sequence at $80 \%$ Naïve Bayesian bootstrap cut-off with 1000 iterations. The sequences used in this study have been deposited in the NCBI Sequence Read Archive under accession number SRP172073.

\section{Statistical analysis}

All samples were standardised by random subsampling to 13,882 reads per sample using the sub.sample command (http://www.mothur.org/wiki/Sub.sample) in Mothur. 
Richness, diversity indices, and rarefaction values were estimated using Mothur. Variation in the relative abundance of the bacterial phyla among the $\mathrm{pH}$ zones was tested using two-way ANOVA in R software package 2.14.2, with habitat type and $\mathrm{pH}$ level as fixed factors, after testing for normality. We used Tukey's Honest Significant Difference test for pairwise comparisons. We used the same procedure to test whether OTUs richness and diversity indices differed across different $\mathrm{pH}$ levels. OTU-based abundance data were first square root transformed to build the Bray-Curtis distance matrix using the vegdist function in the Vegan package of R (Oksanen et al., 2008). We performed a nonmetric multidimensional scaling (NMDS) plot using the metaMDS function in the vegan package of R. This used the BrayCurtis distance matrix to assess patterns in bacterial species composition. A permutational multivariate analysis of variance (PERMANOVA) was performed with 999 permutations using the Adonis function in Vegan R package to test if bacterial community composition differed significantly by $\mathrm{pH}$ levels and habitat type.

The rank order nestedness relationship was also calculated on BINMATNEST (Rodríguez-Gironés and Santamaría, 2006) using default input parameters and null models to test whether the community assemblage in each treatment sample was a subset present in another sample. This approach calculates the p-value for rows and column totals and these were reordered following a packed matrix order from high-to-low nestedness as enumerated by (Dong et al., 2016).

Bacterial co-occurrence network analysis was conducted following methods given by (Faust and Raes, 2012; Lima-Mendez et al., 2015). For each group, OTUs that appeared in three or less samples were removed. The relative abundance of OTUs was then used to construct networks using Spearman's correlation and Kullback-Leibler dissimilarity methods. Randomization generated permutation and bootstrap distributions, and $p$ values were merged by Brown's method and multiple test correlation with Benjamini-Hochberg. Finally, edges 
with $p_{\text {adj }}$ above 0.05 were discarded.

The functional composition of the microbial community was analysed using PICRUSt (Langille et al. 2013) on the OTUs generated from the 16S rRNA data. The PICRUSt program requires a biom-formatted OTU table with OTUs assigned to a Greengenes OTU ID. The 16S OTU table was normalized for copies of the $16 \mathrm{~S}$ rRNA gene and exported as to .biom format for analysis with the software package STAMP (Parks et al 2014). STAMP includes statistical and visualization tools that were used to identify differences in functional potential for the biofilm bacterial communities across different sites along the $\mathrm{pH}$ gradient. . Multiple group comparisons of function abundance (KEGG module predictions) were assessed using analysis of variance (ANOVA) followed by Tukey-Kramer post hoc tests (confidence interval of 0.95 ) and reported with corrected $P$ values (Storey's FDR multiple test correction approach) in STAMP software (Parks et al 2014).

\section{Results}

We obtained 583,036 good quality sequences from 36 samples after rarefying to 13,882 reads per sample, which were classified into 10,296 operational taxonomic units (OTUs) at 97\% similarity level. Most samples showed no sign of reaching an asymptote in OTU richness at the total number of reads available in the rarefaction analysis. This means that more sequences would be required to assess the full taxonomic diversity of bacteria within the biofilms (Fig. S3).

Alpha diversity of the bacterial community associated with biofilms across different $\mathrm{pH}$ levels was calculated using OTU richness and diversity indices. Bacterial OTU richness was significantly different across all intertidal sites at different $\mathrm{pH}$ levels, and highest number of OTUs was observed at sites having the lowest $\mathrm{pH}$ (Fig. 1). The OTU richness differed significantly by $\mathrm{pH}$ level $\left(\mathrm{F}_{2}, 30=27.05, P<0.001\right)$ and by the interaction between $\mathrm{pH}$ and 
habitat type $\left(F_{2,30}=3.12, P=0.05\right)$. Similarly, Shannon index differed significantly in relation to $\mathrm{pH}\left(\mathrm{F}_{2,30}=15.41, P<0.001\right)$ and the interaction between $\mathrm{pH}$ and habitat type $\left(\mathrm{F}_{2}\right.$, $30=7.01, P=0.003$ ), with highest diversity found in sites having the lowest $\mathrm{pH}$ (Fig. 1). However, the community diversity did not differ between the boulder and cliff-face habitats (OTU richness: $\mathrm{F}_{1,30}=0.83, P=0.36$; and Shannon index: $\mathrm{F}_{1,30}=0.08, P=0.77$ ).

The most dominant bacterial sequences recovered in the present study belonged to Cyanobacteria and Bacteroidetes representing 36\% and 34\% of total reads, respectively, followed by Proteobacteria with $23 \%$ of total reads, and less than $3 \%$ for each of the following bacterial phyla: Planctomycetes, Verrucomicrobia, Chloroflexi, Acidobacteria, Actinobacteria, Gemmatimonadetes and Chlorobi. 3\% of sequences remained unclassified.

The relative abundances of phyla in the epilithic bacterial community detected along the $\mathrm{pH} / \mathrm{CO}_{2}$ gradient off Shikine Island showed significant variations across different sampling sites except for Chloroflexi and Chlorobi (Table S1). The strongest shifts were observed in the most abundant bacterial phyla, with a significant decrease in the relative abundance of Cyanobacteria at reduced $\mathrm{pH}$ sites. The relative abundance of Bacteroidetes was decreased at medium and low $\mathrm{pH}$, but then increased at very low $\mathrm{pH}$ sites. However, Proteobacteria exhibited an increase in relative abundance at low $\mathrm{pH}$ then a decrease at extreme low $\mathrm{pH}$ sites. The remaining phyla showed either no consistent patterns or no change in abundance across different sites (Fig. 2). The interaction between $\mathrm{pH}$ levels and habitat types had a more pronounced effect on bacterial community than only $\mathrm{pH}$ level or habitat type. Cyanobacteria were influenced by both factors, with lowest abundance was found in boulder zone and sites having lowest $\mathrm{pH}$. Bacteroidetes were significantly affected only by $\mathrm{pH}$ with their lowest abundance observed at low $\mathrm{pH}$ sites for both boulder and cliff-faced sites. However, Proteobacteria were significantly affected only by habitat types showing a decrease in relative abundance at boulder sites. The interaction $\mathrm{pH}$ levels and habitat types 
had a significant effect on most of detected phyla including Verrucomicrobia, Acidobacteria, Actinobacteria and Gemmatimonadetes. Planctomycetes were significantly affected by $\mathrm{pH}$ levels, habitat types and the interaction $\mathrm{pH}$ levels*habitat types (Fig. 2, Table S1).

More than 25 bacterial orders were detected in our sequences (Fig. 3a). Sphingobacteriales were the most abundant order, with a relative abundance of $13.8 \%$ of total reads but did not differ at both boulder and cliff-face sites along $\mathrm{pH}$ gradient. The relative abundance of almost all detected orders significantly differed in relation to at least one of the studied factors $(\mathrm{pH}$ level, habitat type, and interaction $\mathrm{pH}$ level*habitat type) (Table S2). The orders Oscillatoriales, Cytophagales, Alteromonadales, Phycisphaerales, Kordiimonadales, Chromatiales and Balneola were significantly affected by $\mathrm{pH}$ level, habitat type and the interaction of $\mathrm{pH}$ level and habitat type. However, Flavobacteriales $(12.5 \%$ of total reads) the second common order significantly differed along $\mathrm{pH}$ level and the interaction $\mathrm{pH}$ level*habitat type and not with habitat type, with highest abundance found at ambient $\mathrm{pH}$ for boulder sites and low $\mathrm{pH}$ for cliff-face sites. The relative abundance of Oscillatoriales and Vibrionales was significantly lower at ambient $\mathrm{pH}$ for both boulder and cliff sites. Conversely, Rhodospirillales and Sphingomonadales were significantly greater at low $\mathrm{pH}$ for both habitat types. The remaining orders showed no consistent patterns (Fig. 3a).

At the family level, the biofilm bacterial communities at both boulder and cliff-face sites along $\mathrm{pH}$ gradient were dominated by Saprospiraceae (13.1\% of total reads), Flavobacteriaceae (12\% of total reads), Prochlorotrichaceae ( $7.9 \%$ of total reads), Pleurocapsa family (7.8\% of total reads), Vibrionaceae (6.1\% of total reads), Rivulariaceae (3.9\% of total reads), etc. and had significant differences across $\mathrm{pH}$ level or/and habitat type except for Saprospiraceae $(P>0.05)$ the most abundant family (Table S3). Most of the detected families showed no consistent pattern in response to $\mathrm{pH}$ and/or habitat type (Fig. 3b). For example, Flavobacteriaceae were higher at ambient $\mathrm{pH}$ in boulder sites and at low 
pH in cliff-face sites. Prochlorotrichaceae were lower at ambient $\mathrm{pH}$ in both boulder and cliff sites. Only habitat type had a significant effect on Vibrionaceae and Rivulariaceae where Vibrionaceae represented a minor component of boulder sites ( $0.2 \%$ of total reads) and major component of cliff sites (14\% of total reads), conversely Rivulariaceae were greater in boulder sites (6.5\% of total reads) and lower in cliff sites ( $1.5 \%$ of total reads). Pseudoalteromonadaceae had also lower relative abundance in boulder sites $(<0.01 \%$ of total reads) compared with cliff sites ( $7.5 \%$ of total reads). Pseudoalteromonadaceae were significantly influenced by $\mathrm{pH}$, habitat type and the interaction $\mathrm{pH}$ level*Habitat type, with lower abundance observed at lower $\mathrm{pH}$ (Fig. 3b).

A non-metric multidimensional scaling (NMDS) using Bray-Curtis distance indicated that both $\mathrm{pH}$ levels and habitat type influenced bacterial community composition (Fig. 4). A permutational multivariate analysis of variance (PERMANOVA) results showed that bacterial community composition was not only affected by $\mathrm{pH}$ level $\left(\mathrm{F}_{2,29}=3.54, P=0.001\right.$; Table 2) and habitat type $\left(\mathrm{F}_{1,29}=8.62, P=0.001\right.$; Table 2$)$, but also by the interaction between $\mathrm{pH}$ level and habitat type $\left(\mathrm{F}_{2,29}=3.65, P=0.001\right.$; Table 2$)$.

Nestedness analysis showed that bacterial communities followed a nested structure ( $p$ $<0.0001)$ across different $\mathrm{pH}$ levels. We generated a packed matrix order of all samples, in which the nestedness of each sample was categorised from high to low, and the lower ones are nested in the higher ones (Table S4). Samples having the lowest $\mathrm{pH}$ in boulder habitat and samples having ambient $\mathrm{pH}$ in cliff-face habitat had the lowest rank of nestedness compared to the other sites. Thus, the OTU composition of other sites could be a subset of the bacterial community in the 'Boulder-very low' and 'Cliff-ambient' sites.

Fig. 5 and Fig. 6 illustrated the interactions between taxa across different pH levels. Associations of bacterial taxa at very low $\mathrm{pH}$ sites outnumbered low and ambient $\mathrm{pH}$ sites, no matter the rock type. Positive edges were higher than negative edges, except for low $\mathrm{pH}$ cliff 
and ambient boulder sites where the number of positive edges was equal with negative edges (Fig. 5). Furthermore, non-random edges distribution with regard to phylum was observed. We found that both intra-phylum and inter-phylum interaction edges of Bacteroidetes were the highest in all samples (Fig. 6).

The functional classification based on KEGG module predictions (Fig. S4) revealed that biofilm microbial communities show some a significant shift in most of the functions in Boulder and Cliff sites across different $\mathrm{pH}$ levels. Analysis of PICRUSt-predicted functional profiles for methane metabolic pathways suggest a decrease in gene abundance at lower $\mathrm{pH}$ for both boulder and cliff sites (Fig. 7a). Sulfur metabolism showed the opposite pattern with greater gene abundance at lower $\mathrm{pH}$ (Fig. 7b). The analysis of nitrogen metabolic pathway suggested no significant difference in gene abundance at both habitat types across different pH level (ANOVA, Tukey-Kramer, $P<0.05$; Fig. $7 \mathrm{c}$ ). Genes related to energy metabolic pathways increased at lower $\mathrm{pH}$ at both boulder and cliff sites (Fig. 7d). Carbon fixation potential in Prokaryotes showed an increase then a decrease in gene abundance related to carbon fixation in Prokaryotes at boulder sites along $\mathrm{pH}$ gradient. These genes decreased at medium $\mathrm{pH}$ then increased at low $\mathrm{pH}$ at cliff sites (Fig. 7e). The opposite pattern was observed for genes related to carbon fixation pathway in photosynthetic organisms (Fig. 7f).

\section{Discussion}

We found that bacterial community composition in biofilms on two types of rocky shore habitat was affected at $\mathrm{CO}_{2}$ seeps (Heat map Fig). Pre-industrial, present day and projected future levels of seawater $p \mathrm{CO}_{2}$ each had their own discrete communities of biofilm bacteria, raising the possibility that the transition from $300-400 \mathrm{ppm} \mathrm{CO}_{2}$ in ocean seawater over the past 200 years has already affected biofilm communities worldwide. Biofilm growing at even higher than present-day levels of $\mathrm{CO}_{2}$ increased in bacterial biodiversity. 
This is very similar to the biofilm shifts recorded from present-day to high $p \mathrm{CO}_{2}$ conditions in the Mediterranean Sea (Lidbury et al., 2012; Kerfahi et al., 2014) and in mesocosm conditions (Witt et al., 2011) and suggests a general response of biofilms to increasing $\mathrm{CO}_{2}$. Responses to ocean acidification conditions varied between bacterial taxa, some of these increasing whilst others decreased in relative abundance resulting in changes in species richness and diversity (Fig. 1, Fig. 2 and Fig. 3). These findings mirror those of Taylor et al. (2014) at $\mathrm{CO}_{2}$ seeps in Italy, who found that shifts in bacterial biofilm communities involved a similar set of bacterial phyla to those recorded in our study (Fig. 2). Marine bacterioplankton communities also respond to changes in seawater $\mathrm{CO}_{2}$ with changes in community composition, yet the functions of those communities remain resilient to acidification (Lindh et al., 2013; Lin et al., 2018), as predicted by Joint et al. (2011).

Holobiont communities can also be affected by ocean acidification conditions. Meron et al. (2012) reported shifts in coral bacterial community composition along a $\mathrm{pH}$ gradient of 8.1-7.3 caused by $\mathrm{CO}_{2}$ seeps in Italy but found that many taxa were resilient. However, Webster et al. (2016) carried out an eight week-long mesocosm experiment and found that coral-associated bacterial taxa were tolerant of elevated $p \mathrm{CO}_{2}$ (including Proteobacteria, Bacteroidetes, Fusobacteria, Verrucomicrobia, Chloroflexi and Planctomycetes) with no community shifts in these taxa between $\mathrm{pH} 8.1\left(p \mathrm{CO}_{2} 479-499 \mu \mathrm{atm}\right)$ and $\mathrm{pH} 7.9\left(p \mathrm{CO}_{2}\right.$ 738-835 $\mu$ atm) although they acknowledged that a longer-term experiment might have revealed an effect. In contrast, shifts in hard substratum biofilm microbial community structure were recorded by Webster et al. (2013) who simulated the effects of ocean acidification by bubbling $\mathrm{CO}_{2}$ into flow-through aquaria and recorded the appearance of new taxa within bacterial biofilm communities as the $\mathrm{pH}$ fell. This is similar to the responses we found in relation to $\mathrm{pH}$ treatments on Japanese rocky shores, suggesting that perhaps holobiont communities are under tighter control exerted by the host, compared to rocky 
biofilm communities.

It is interesting that there are no major shifts in relative abundance functional groups, for example $\mathrm{N}$ fixers and photosynthesizers. Both taxonomic and functional analysis showed that major groups of bacteria (at family and genus levels) remained abundant at the higher pCO2 levels suggesting that the primary productivity and nutrient cycling of the system did not fundamentally changed, and that most essential biogeochemical functions were still present (Fig. 2) such as the nitrogen fixing activities Cyanobacteria and Chloroflexi.. It is also interesting to note that chemotrophs such as Halothiobacillus, Guyparkeria, Thiobacillus, Sulfuritortus, Nitrosomonas, Gallionella and Ferriphaeselus are absent even at the lowest $\mathrm{pH}$ treatments. This negative result simultaneously suggests that there may be little change in biogeochemical cycling as a result of such coastal biofilms, and confirms that the $\mathrm{CO}_{2}$-rich vents are not contaminated with S-containing gases and are indeed pure $\mathrm{CO}_{2}$ as was originally proposed based on gas and seawater chemistry measurements.

However, our conclusions on functional attributes of the biofilms are based only on taxonomic composition and relative abundances. It would be interesting to study the metagenome of these systems as a range of microbial functional processes are thought to be sensitive to ocean $\mathrm{pH}$ shifts (Das and Mangwani, 2015).

Network analysis revealed that sites having very low $\mathrm{pH}$ were more connected than low and ambient pH sites (Fig. 5 and Fig. 6). Network analysis which is based on statistically significant tests of correlation helps to illustrate interactions between taxa, and between particular taxa and particular gene functions (Barberán et al., 2012; Faust and Raes, 2012; Mendes et al., 2014). In networks based on correlation between bacterial OTUs, co-presence associations were stronger than mutual exclusion, implying that most interactions were positive at all studied $\mathrm{pH}$ levels, a pattern which is consistent with Lima-Mendez et al., (2015). However, the nearly equal proportions of positive and negative edges demonstrate 
that taxon-taxon interactions may be regulated by environmental factors. An intact speciesrich system would be expected to have greater network complexity due to stable and predictable interactions (Wagg et al., 2014). Our results showed that the sites with very low seawater $\mathrm{pH}$ had more complex networks and higher diversity, which indicates that these biofilm communities experienced greater environmental heterogeneity (Lin et al., 2018). Bacteroidetes exhibited the most intra-phylum and inter-phylum associations, suggesting that Bacteroidetes play crucial roles in the biofilm communities we sampled.

Overall, we found that bacterial biofilms had considerable resilience to ocean water acidification, retaining a similar high diversity and functional structure, and stronger network complexity. This contrasts with the simplification of the taxonomic and functional diversity system of larger organisms brought about by decreasing $\mathrm{pH}$ in these same coastal systems. Agostini et al. (2018) showed that at the acidified sites on both of the habitat types we studied, biofilm and turf algae predominated. The normal succession that occurs on rocky shores had been truncated with simpler and less diverse macrobenthic communities, in line with the findings of Kroeker et al. (2013) and Brown et al. (2018).

There are likely to be multiple mechanisms that drive changes in biofilm bacterial composition along gradients of increasingly acidified conditions. These may include the direct effects of low $\mathrm{pH}$, or low carbonate, or high $p \mathrm{CO}_{2}$ as well as the indirect effects that occur due to changes in habitat and/or organism interactions. We consider it likely that the bacterial community shifts we observed along $\mathrm{pH}$ gradients were party driven by changes in the broader ecology of the rocky shore system food webs. At our high $p \mathrm{CO}_{2}$ sites there was a marked reduction in calcified grazers such as littorinid snails, limpets and chitons and an increase in eukaryotic primary producers, such as diatoms (Agostini et al., 2018) all of which would be expected to affect the thickness, extent and composition of biofilm communities.

To date, there had been no other studies on the effects of ocean acidification on 
biofilms in Asia. Our comparison of marine biofilms along a natural $\mathrm{pH}$ gradient in Japan supports the view that while there may be pervasive effects of rising $p \mathrm{CO}_{2}$ levels on marine bacterial biofilm communities, the functional effects may not be major. This warrants further investigation, given that acidification may disrupt biofilm settlement cues for commercially important shellfish, and may affect grazing habitat for a range of marine animals.

Our observations contrast with mounting evidence that increasing levels of seawater $p \mathrm{CO}_{2}$ simplifies marine habitats, maintaining them in an early successional state (Kroeker et al., 2013; Brown et al., 2018). Agostini et al. (2018) showed that biodiverse rocky shore communities (including calcareous macroflora and fauna) were gradually replaced by simpler, less biodiverse communities that are dominated by non-calcified algae and biofilms in areas affected by periods of low carbonate saturation and high dissolved inorganic carbon. Here we showed that at the microbial level bacterial diversity and biofilm connectedness increased, and while communities shifted with unknown effects on biofilm function. Whilst the biofilms will still be fixing and cycling carbon and nutrients, it is possible that a range of other functions (e.g. provision of settlement cues) may be affected. Given the importance of biofilms to coastal ecology, changes in their composition due to globally rising $p \mathrm{CO}_{2}$ levels requires further investigation to assess the implications for marine ecosystem function.

\section{Acknowledgments}

We thank Prof. Rich Boden, University of Plymouth, United Kingdom for his suggestions in improving the paper. We also thank Dr. Matthew Chidozie Ogwe, University of Camerino, Italy for his assistance on data analyses and paper editing. 


\section{References}

Agostini, S., Harvey, B. P., Wada, S., Kon, K., Milazzo, M., Inaba, K., et al. (2018). Ocean acidification drives community shifts towards simplified non-calcified habitats in a subtropical-temperate transition zone. Sci. Rep. 8, 11354. doi:10.1038/s41598-01829251-7.

Azam, F., and Malfatti, F. (2007). Microbial structuring of marine ecosystems. Nat. Rev. Microbiol. 5, 782. doi:10.1038/nrmicro1747.

Barberán A, Bates S T, Casamayor E O, Fierer N. 2012. Using network analysis to explore co-occurrence patterns in soil microbial communities. The ISME journal. 6: 343.

Brown, N. E. M., Milazzo, M., Rastrick, S. P. S., Hall-Spencer, J. M., Therriault, T. W., and Harley, C. D. G. (2018). Natural acidification changes the timing and rate of succession, alters community structure, and increases homogeneity in marine biofouling communities. Glob. Change Biol. 24, e112-e127. doi:10.1111/gcb.13856.

Chun, J., Lee, J.-H., Jung, Y., Kim, M., Kim, S., Kim, B. K., et al. (2007). EzTaxon: a webbased tool for the identification of prokaryotes based on 16S ribosomal RNA gene sequences. Int. J. Syst. Evol. Microbiol. 57, 2259-2261. doi:10.1099/ijs.0.64915-0.

Connell, S. D., Kroeker, K. J., Fabricius, K. E., Kline, D. I., and Russell, B. D. (2013). The other ocean acidification problem: $\mathrm{CO}_{2}$ as a resource among competitors for ecosystem dominance. Philos. Trans. R. Soc. B Biol. Sci. 368, 20120442. doi:10.1098/rstb.2012.0442.

Cornwall, C. E., Revill, A. T., Hall-Spencer, J. M., Milazzo, M., Raven, J. A., and Hurd, C. L. (2017). Inorganic carbon physiology underpins macroalgal responses to elevated $\mathrm{CO}_{2}$. Sci. Rep. 7, 46297. doi:10.1038/srep46297.

Das, S., and Mangwani, N. (2015). Ocean acidification and marine microorganisms: responses and consequences. Oceanologia 57, 349-361. doi:10.1016/j.oceano.2015.07.003.

de Carvalho, C. C. (2018). Marine biofilms: A successful microbial strategy with economic implications. Front. Mar. Sci. 5, 126. doi:10.3389/fmars.2018.00126.

Decho, A. W. (2000). Microbial biofilms in intertidal systems: an overview. Cont. Shelf Res. 20, 1257-1273. doi:10.1016/S0278-4343(00)00022-4.

Dickson, A. G. (1990). Thermodynamics of the dissociation of boric acid in potassium chloride solutions from 273.15 to 318.15 K. J. Chem. Eng. Data 35, 253-257. doi:10.1021/je00061a009.

Dickson, A. G., and Millero, F. J. (1987). A comparison of the equilibrium constants for the dissociation of carbonic acid in seawater media. Deep Sea Res. Part Oceanogr. Res. Pap. 34, 1733-1743. doi:10.1016/0198-0149(87)90021-5.

Dong, K., Tripathi, B., Moroenyane, I., Kim, W., Li, N., Chu, H., et al. (2016). Soil fungal community development in a high Arctic glacier foreland follows a directional replacement model, with a mid-successional diversity maximum. Sci. Rep. 6, 26360. 
doi:10.1038/srep26360.

Edgar, R. C., Haas, B. J., Clemente, J. C., Quince, C., and Knight, R. (2011). UCHIME improves sensitivity and speed of chimera detection. Bioinformatics 27, 2194-2200. doi:10.1093/bioinformatics/btr381.

Fabricius, K. E., Langdon, C., Uthicke, S., Humphrey, C., Noonan, S., De'ath, G., et al. (2011). Losers and winners in coral reefs acclimatized to elevated carbon dioxide concentrations. Nat. Clim. Change 1, 165-169. doi:10.1038/nclimate1122.

Faust K, Raes J. 2012. Microbial interactions: From networks to models. Nature Reviews Microbiology. 10: 538-550.

Hall-Spencer, J. M., Rodolfo-Metalpa, R., Martin, S., Ransome, E., Fine, M., Turner, S. M., et al. (2008). Volcanic carbon dioxide vents show ecosystem effects of ocean acidification. Nature 454, 96-99. doi:10.1038/nature07051.

Hassenrück, C., Hofmann, L. C., Bischof, K., and Ramette, A. (2015). Seagrass biofilm communities at a naturally $\mathrm{CO}_{2}$-rich vent. Environ. Microbiol. Rep. 7, 516-525. doi:10.1111/1758-2229.12282.

Hassenrück, C., Tegetmeyer, H. E., Ramette, A., Fabricius, K. E., and Handling editor: Woodson CB (2017). Minor impacts of reduced $\mathrm{pH}$ on bacterial biofilms on settlement tiles along natural $\mathrm{pH}$ gradients at two $\mathrm{CO}_{2}$ seeps in Papua New Guinea. ICES J. Mar. Sci. 74, 978-987. doi:10.1093/icesjms/fsw204.

Huse, S. M., Welch, D. M., Morrison, H. G., and Sogin, M. L. (2010). Ironing out the wrinkles in the rare biosphere through improved OTU clustering. Environ. Microbiol. 12, 1889-1898. doi:10.1111/j.1462-2920.2010.02193.x.

Johnson, R. V., Brownlee, C., Milazzo, M., and Hall-Spencer, M. J. (2015). Marine microphytobenthic assemblage shift along a natural shallow-water $\mathrm{CO}_{2}$ gradient subjected to multiple environmental stressors. J. Mar. Sci. Eng. 3. doi:10.3390/jmse3041425.

Joint, I., Doney, S. C., and Karl, D. M. (2011). Will ocean acidification affect marine microbes? ISME J. 5, 1. doi:10.1038/ismej.2010.79.

Kerfahi, D., Hall-Spencer, J. M., Tripathi, B. M., Milazzo, M., Lee, J., and Adams, J. M. (2014). Shallow water marine sediment bacterial community shifts along a natural $\mathrm{CO}_{2}$ gradient in the Mediterranean Sea off Vulcano, Italy. Microb. Ecol. 67, 819-828. doi:10.1007/s00248-014-0368-7.

Krause, E., Wichels, A., Giménez, L., Lunau, M., Schilhabel, M. B., and Gerdts, G. (2012). Small changes in $\mathrm{pH}$ have direct effects on marine bacterial community composition: a microcosm approach. PLoS One 7, e47035. doi:10.1371/journal.pone.0047035.

Kroeker, K. J., Gambi, M. C., and Micheli, F. (2013). Community dynamics and ecosystem simplification in a high- $\mathrm{CO}_{2}$ ocean. Proc. Natl. Acad. Sci. U. S. A. 110, 12721-12726. doi:10.1073/pnas.1216464110.

Lau, S. C., Thiyagarajan, V., Cheung, S. C., and Qian, P.-Y. (2005). Roles of bacterial 
community composition in biofilms as a mediator for larval settlement of three marine invertebrates. Aquat. Microb. Ecol. 38, 41-51. doi:10.3354/ame038041.

Lauber, C. L., Strickland, M. S., Bradford, M. A., and Fierer, N. (2008). The influence of soil properties on the structure of bacterial and fungal communities across land-use types. Soil Biol. Biochem. 40, 2407-2415. doi:10.1016/j.soilbio.2008.05.021.

Lewis, J. R. (1964). The Ecology of Rocky Shores. London, UK: English Universities Press.

Lidbury, I., Johnson, V., Hall-Spencer, J. M., Munn, C. B., and Cunliffe, M. (2012). Community-level response of coastal microbial biofilms to ocean acidification in a natural carbon dioxide vent ecosystem. Mar. Pollut. Bull. 64, 1063-1066. doi:10.1016/j.marpolbul.2012.02.011.

Lima-Mendez G, Faust K, Henry N, Decelle J, Colin S, Carcillo F, Chaffron S, IgnacioEspinosa J C, Roux S, Vincent F. 2015. Determinants of community structure in the global plankton interactome. Science. 348: 1262073.

Lin, X., Huang, R., Li, Y., Li, F., Wu, Y., Hutchins, D. A., et al. (2018). Interactive network configuration maintains bacterioplankton community structure under elevated $\mathrm{CO}_{2}$ in a eutrophic coastal mesocosm experiment. Biogeosciences 15, 551-565. doi:10.5194/bg-15-551-2018.

Lindh, M. V., Riemann, L., Baltar, F., Romero-Oliva, C., Salomon, P. S., Granéli, E., et al. (2013). Consequences of increased temperature and acidification on bacterioplankton community composition during a mesocosm spring bloom in the Baltic Sea. Environ. Microbiol. Rep. 5, 252-262. doi:10.1111/1758-2229.12009.

Liu, J., Weinbauer, M. G., Maier, C., Dai, M., and Gattuso, J. P. (2010). Effect of ocean acidification on microbial diversity and on microbe-driven biogeochemistry and ecosystem functioning. Aquat. Microb. Ecol. 61, 291-305. doi:10.3354/ame01446.

Mehrbach, C., Culberson, C. H., Hawley, J. E., and Pytkowicz, R. M. (1973). Measurement of the apparent dissociation constants of carbonic acid in seawater at atmospheric pressure. Limnol. Oceanogr. 18, 897-907. doi:10.4319/lo.1973.18.6.0897.

Mendes L W, Kuramae E E, Navarrete A A, Van Veen J A, Tsai S M. 2014. Taxonomical and functional microbial community selection in soybean rhizosphere. The ISME journal. 8: $1577-1587$.

Meron, D., Rodolfo-Metalpa, R., Cunning, R., Baker, A. C., Fine, M., and Banin, E. (2012). Changes in coral microbial communities in response to a natural $\mathrm{pH}$ gradient. ISME J. 6, 1775. doi:10.1038/ismej.2012.19.

Meyer, F., Paarmann, D., D’Souza, M., Olson, R., Glass, E. M., Kubal, M., et al. (2008). The metagenomics RAST server-a public resource for the automatic phylogenetic and functional analysis of metagenomes. BMC Bioinformatics 9, 386. doi:10.1186/14712105-9-386.

Morrow, K. M., Bourne, D. G., Humphrey, C., Botté, E. S., Laffy, P., Zaneveld, J., et al. (2014). Natural volcanic $\mathrm{CO}_{2}$ seeps reveal future trajectories for host-microbial associations in corals and sponges. Isme J. 9, 894. doi:10.1038/ismej.2014.188. 
O'Brien, P. A., Smith, H. A., Fallon, S., Fabricius, K., Willis, B. L., Morrow, K. M., et al. (2018). Elevated $\mathrm{CO}_{2}$ has little influence on the bacterial communities associated with the pH-tolerant coral, massive Porites spp. Front. Microbiol. 9, 2621. doi:10.3389/fmicb.2018.02621.

Oksanen, J., Kindt, R., Legendre, P., O’Hara, B., Simpson, G. L., Solymos, P., et al. (2008). The vegan package. Community Ecol. Packag.-Forge R-Proj. Orgprojectsvegan.

Pierrot, D., Lewis, E., and Wallace, D. W. R. (2006). MS Excel Program Developed for $\mathrm{CO}_{2}$ System Calculations, ORNL/CDIAC-105. Oak Ridge, Tennessee.

Porzio, L., Buia, M. C., and Hall-Spencer, J. M. (2011). Effects of ocean acidification on macroalgal communities. J. Exp. Mar. Biol. Ecol. 400, 278-287. doi:10.1016/j.jembe.2011.02.011.

Qian, P.-Y., Lau, S. C., Dahms, H.-U., Dobretsov, S., and Harder, T. (2007). Marine biofilms as mediators of colonization by marine macroorganisms: implications for antifouling and aquaculture. Mar. Biotechnol. 9, 399-410. doi:10.1007/s10126-007-9001-9.

Rastrick, S. S. P., Graham, H., Azetsu-Scott, K., Calosi, P., Chierici, M., Fransson, A., et al. (2018). Using natural analogues to investigate the effects of climate change and ocean acidification on Northern ecosystems. ICES J. Mar. Sci., fsy128-fsy128. doi:10.1093/icesjms/fsy128.

Riebesell, U., and Gattuso, J.-P. (2015). Lessons learned from ocean acidification research. Nat. Clim. Change 5, 12-14. doi:10.1038/nclimate2456.

Rodríguez-Gironés, M. A., and Santamaría, L. (2006). A new algorithm to calculate the nestedness temperature of presence-absence matrices. J. Biogeogr. 33, 924-935. doi:10.1111/j.1365-2699.2006.01444.x.

Schloss, P. D., Westcott, S. L., Ryabin, T., Hall, J. R., Hartmann, M., Hollister, E. B., et al. (2009). Introducing mothur: open-source, platform-independent, communitysupported software for describing and comparing microbial communities. Appl. Environ. Microbiol. 75, 7537-7541. doi:10.1128/AEM.01541-09.

Sunday, J. M., Fabricius, K. E., Kroeker, K. J., Anderson, K. M., E, B. N., Barry, J. P., et al. (2017). Ocean acidification can mediate biodiversity shifts by changing biogenic habitat. Nat. Clim. Change 7, 81-85. doi:10.1038/nclimate3161.

Taylor, J. D., Ellis, R., Milazzo, M., Hall-Spencer, J. M., and Cunliffe, M. (2014). Intertidal epilithic bacteria diversity changes along a naturally occurring carbon dioxide and $\mathrm{pH}$ gradient. FEMS Microbiol. Ecol. 89, 670-678. doi:10.1111/1574-6941.12368.

Thompson, R., Norton, T., and Hawkins, S. (2004). Physical stress and biological control regulate the producer-consumer balance in intertidal biofilms. Ecology 85, 13721382. doi:10.1890/03-0279.

Tolker-Nielsen, T., and Molin, S. (2000). Spatial organization of microbial biofilm communities. Microb. Ecol. 40, 75-84. doi:10.1007/s002480000057.

Tripathi, B. M., Kim, M., Singh, D., Lee-Cruz, L., Lai-Hoe, A., Ainuddin, A., et al. (2012). 
Tropical soil bacterial communities in Malaysia: $\mathrm{pH}$ dominates in the equatorial tropics too. Microb. Ecol. 64, 474-484. doi:10.1007/s00248-012-0028-8.

Uppström, L. R. (1974). The boron/chlorinity ratio of deep-sea water from the Pacific Ocean. Deep Sea Res. Oceanogr. Abstr. 21, 161-162. doi:10.1016/0011-7471(74)90074-6.

Wagg C, Bender S F, Widmer F, van der Heijden M G. 2014. Soil biodiversity and soil community composition determine ecosystem multifunctionality. Proceedings of the National Academy of Sciences. 111: 5266-5270.

Webster, N., Negri, A., Botté, E., Laffy, P., Flores, F., Noonan, S., et al. (2016). Hostassociated coral reef microbes respond to the cumulative pressures of ocean warming and ocean acidification. Sci. Rep. 6, 19324. doi:10.1038/srep19324.

Webster, N., Negri, A., Flores, F., Humphrey, C., Soo, R., Botte, E., et al. (2013). Near-future ocean acidification causes differences in microbial associations within diverse coral reef taxa. Environ. Microbiol. Rep. 5, 243-251. doi:10.1111/1758-2229.12006.

Weinbauer, M. G., Mari, X., and Gattuso, J.-P. (2011). "Effect of ocean acidification on the diversity and activity of heterotrophic marine microorganisms," in Ocean Acidification (Oxford, UK: Oxford University Press), 83-98.

Williams, G. A., Davies, M. S., and Nagarkar, S. (2000). Primary succession on a seasonal tropical rocky shore: the relative roles of spatial heterogeneity and herbivory. Mar. Ecol. Prog. Ser. 203, 81-94. doi:10.3354/meps203081.

Witt, V., Wild, C., Anthony, K. R. N., Diaz-Pulido, G., and Uthicke, S. (2011). Effects of ocean acidification on microbial community composition of, and oxygen fluxes through, biofilms from the Great Barrier Reef. Environ. Microbiol. 13, 2976-2989. doi:10.1111/j.1462-2920.2011.02571.x.

Wootton, J. T., Pfister, C. A., and Forester, J. D. (2008). Dynamic patterns and ecological impacts of declining ocean $\mathrm{pH}$ in a high-resolution multi-year dataset. Proc. Natl. Acad. Sci. U. S. A. 105, 18848-18853. doi:10.1073/pnas.0810079105.

Yachi, S., and Loreau, M. (1999). Biodiversity and ecosystem productivity in a fluctuating environment: the insurance hypothesis. Proc. Natl. Acad. Sci. U. S. A. 96, 1463-1468. doi:10.1073/pnas.96.4.1463. 


\section{Table legends}

Table 1. Sea water chemistry across different sampling sites along $\mathrm{pH}$ gradient.

Table 2. Results of multivariate PERMANOVA showing significant differences in biofilm bacterial community composition between different sites along $\mathrm{pH}$ gradient.

\section{Figure legends}

Fig. 1. Biofilm bacterial alpha-diversity (mean $\pm \mathrm{SE}$ ) at different seawater $\mathrm{pH}$ levels in Shikine Island, Japan. Variation of OTUs richness in (a) boulder sites and (b) cliff sites. And variation of Shannon index (c) boulder sites and (d) cliff sites.

Fig. 2. Relative abundance of biofilm bacterial phyla detected along a pH gradient in Shikine Island, Japan.

Fig. 3. Relative abundance of biofilm bacterial taxa detected along a $\mathrm{pH}$ gradient in Shikine Island, Japan at (a) order level and (b) family level.

Fig. 4. NMDS ordination of total bacterial community composition among (a) different $\mathrm{pH}$ levels and (b) habitat types, based on Bray-Curtis distance.

Fig. 5. Frequency of co-occurrence patterns of sampled sites along a pH gradient in Shikine Island, Japan.

Fig. 6. Number of inter-Phylum and intra-Phylum co-presences and mutual exclusions of sampled sites (A: very low cliff site; B: low cliff site; C: ambient cliff site; D: very low boulder site; E: low boulder site; F: ambient boulder site).

Fig. 7. Box plot representing the relative abundance of the (a) Methane metabolism, (b) Sulphur metabolism, (c) Nitrogen metabolism, (d) Energy metabolism, (e) Carbon fixation in Prokaryotes and (f) Carbon fixation in photosynthetic organisms. The analysis was based on KEGG module 
predictions using $16 \mathrm{~S}$ data with the software PICRUSt. Results from multiple group comparisons in function abundance (ANOVA, Tukey-Kramer, $P<0.05$ ) is reported as corrected $P$-value (Storey's FDR multiple test correction approach). The median value is shown as a line within the box and the mean value as a star. Error bars represent standard deviations.

\section{Supplementary Online Material}

Table S1. Results from two-way ANOVA showing the variation of the relative abundance of biofilm bacterial phyla across different sites.

Table S2. Results from two-way ANOVA showing the variation of the relative abundance of biofilm bacterial orders across different sites.

Table S3. Results from two-way ANOVA showing the variation of the relative abundance of biofilm bacterial families across different sites.

Table S4. Samples of "Boulder-Very low" and "Cliff-Ambient" sites formed the lowest nest while the other samples are basically a subset of these.

Fig. S1. Location of sample sites off Shikine Island, Japan.

Fig. S2. Rock biofilm sampling along a pH gradient off Shikine Island, Japan.

Fig. S3. Rarefaction curves comparing rock biofilm bacterial communities along a seawater $\mathrm{pH}$ gradient off Shikine Island, Japan.

Fig. S4. Predicted differences in biofilm bacterial functional categories (PICRUSt) across boulder and cliff sites off Shikine Island, Japan. 


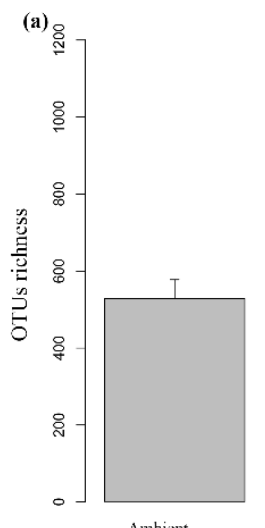

Ambient

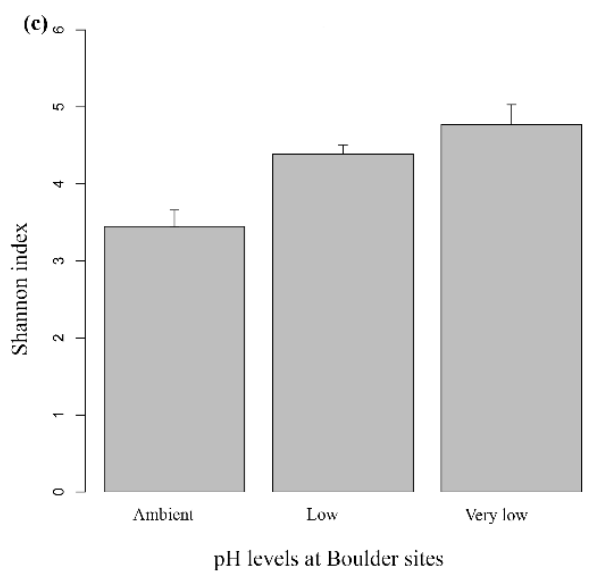

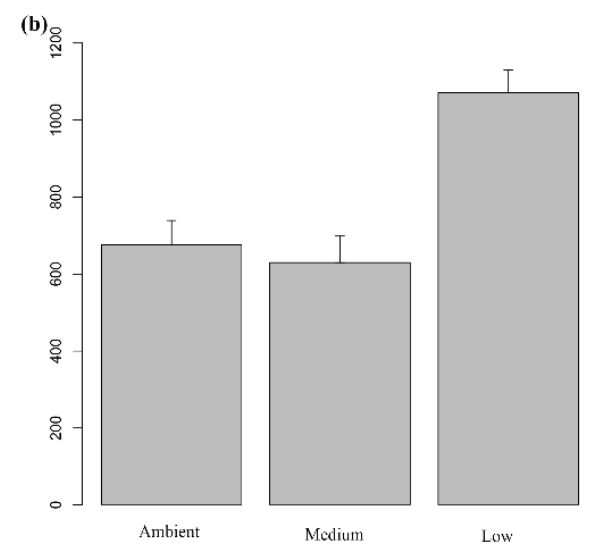

(d)

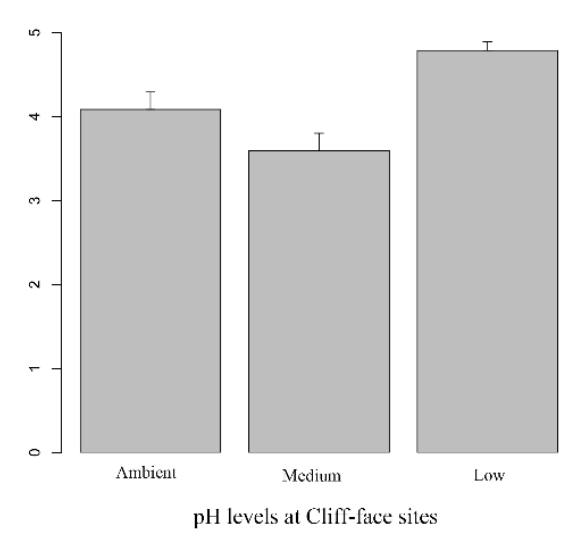

Fig. 1. Biofilm bacterial alpha-diversity (mean $\pm \mathrm{SE}$ ) at different seawater $\mathrm{pH}$ levels in Shikine Island, Japan. Variation of OTUs richness in (a) boulder sites and (b) cliff sites. And variation of Shannon index (c) boulder sites and (d) cliff sites. 


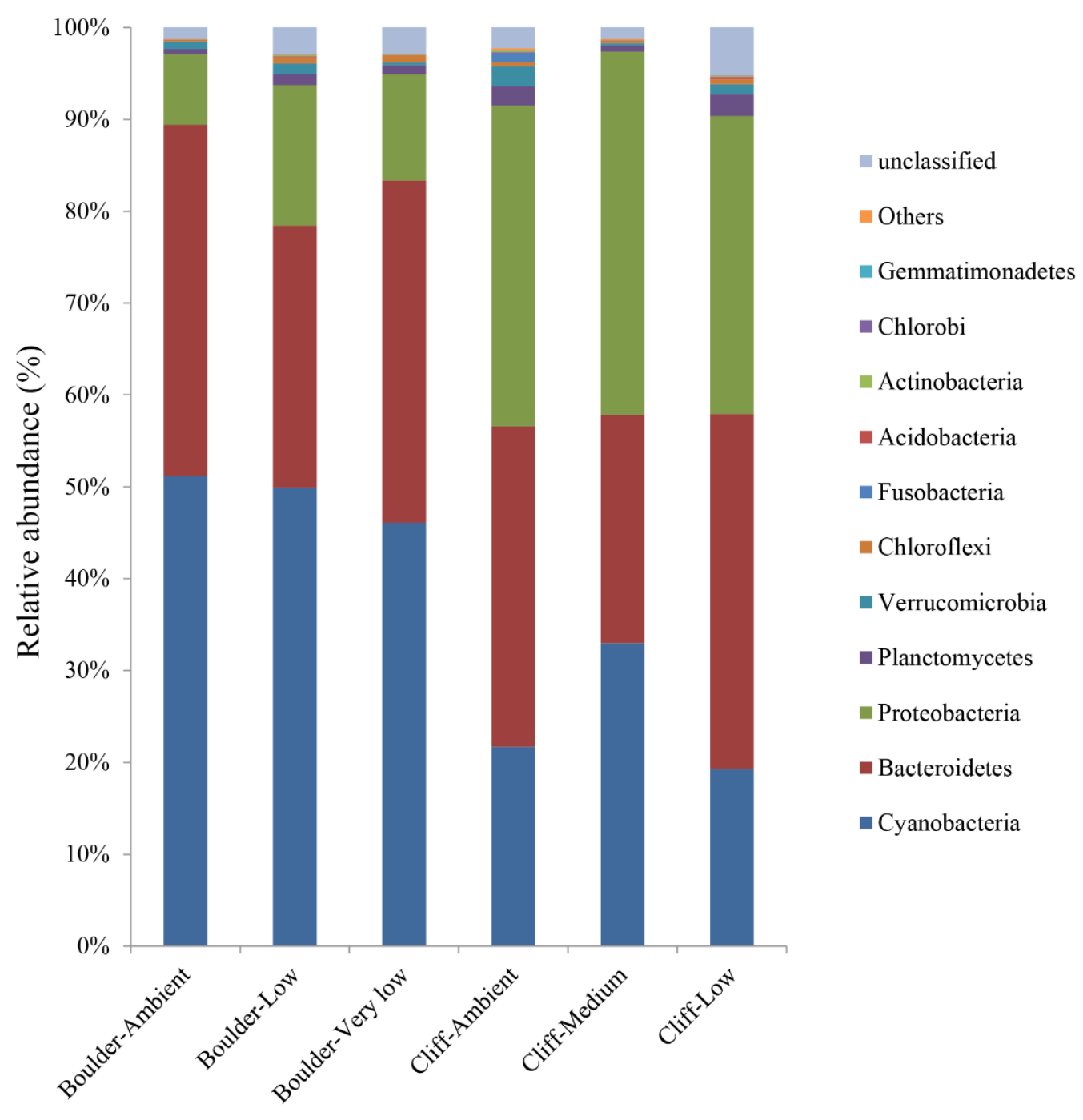

Fig. 2. Relative abundance of biofilm bacterial phyla detected along different sites in Shikine Island, Japan. 


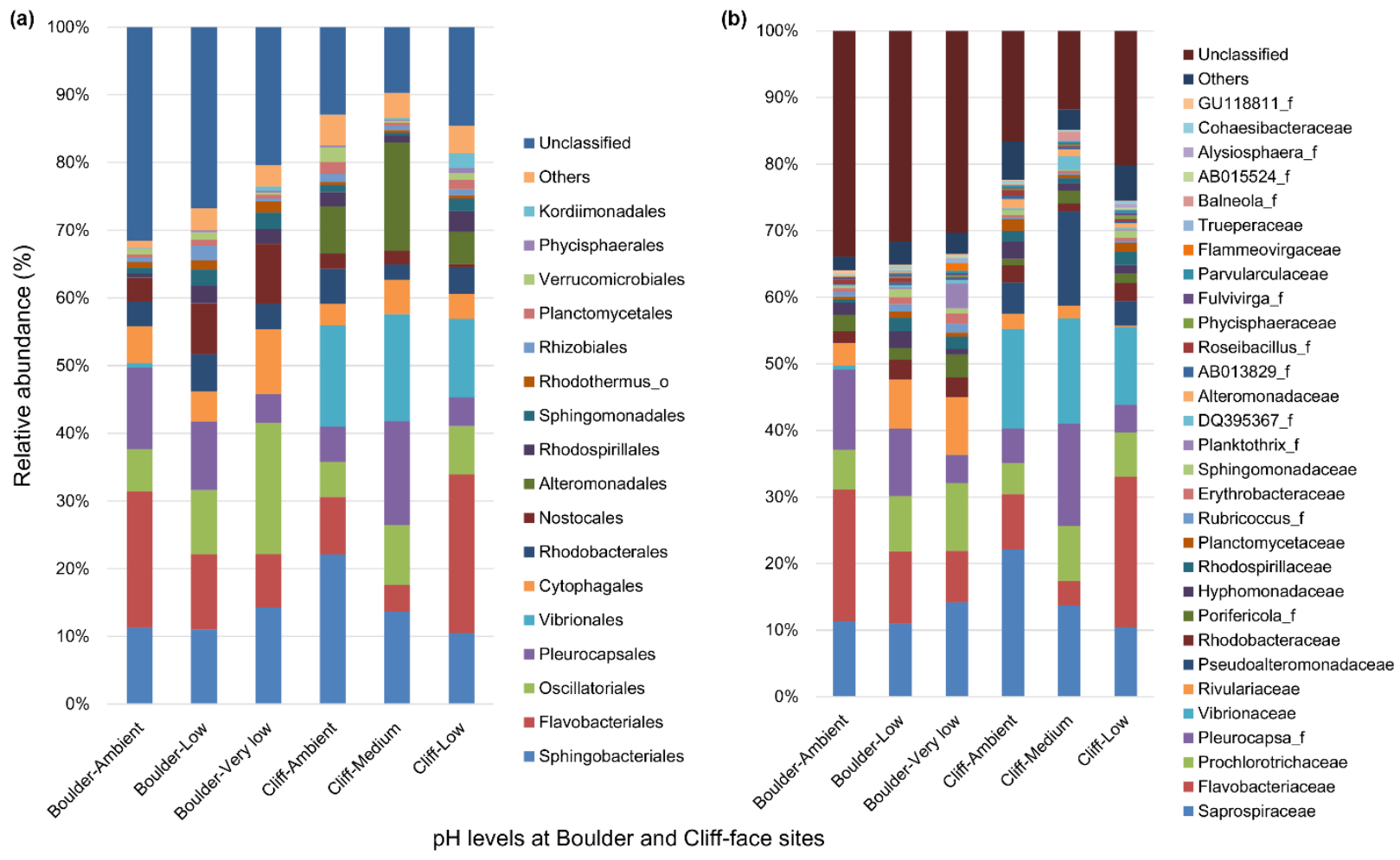

Fig. 3. Relative abundance of biofilm bacterial taxa detected along a $\mathrm{pH}$ gradient in Shikine Island, Japan at a) order level and b) family level. 

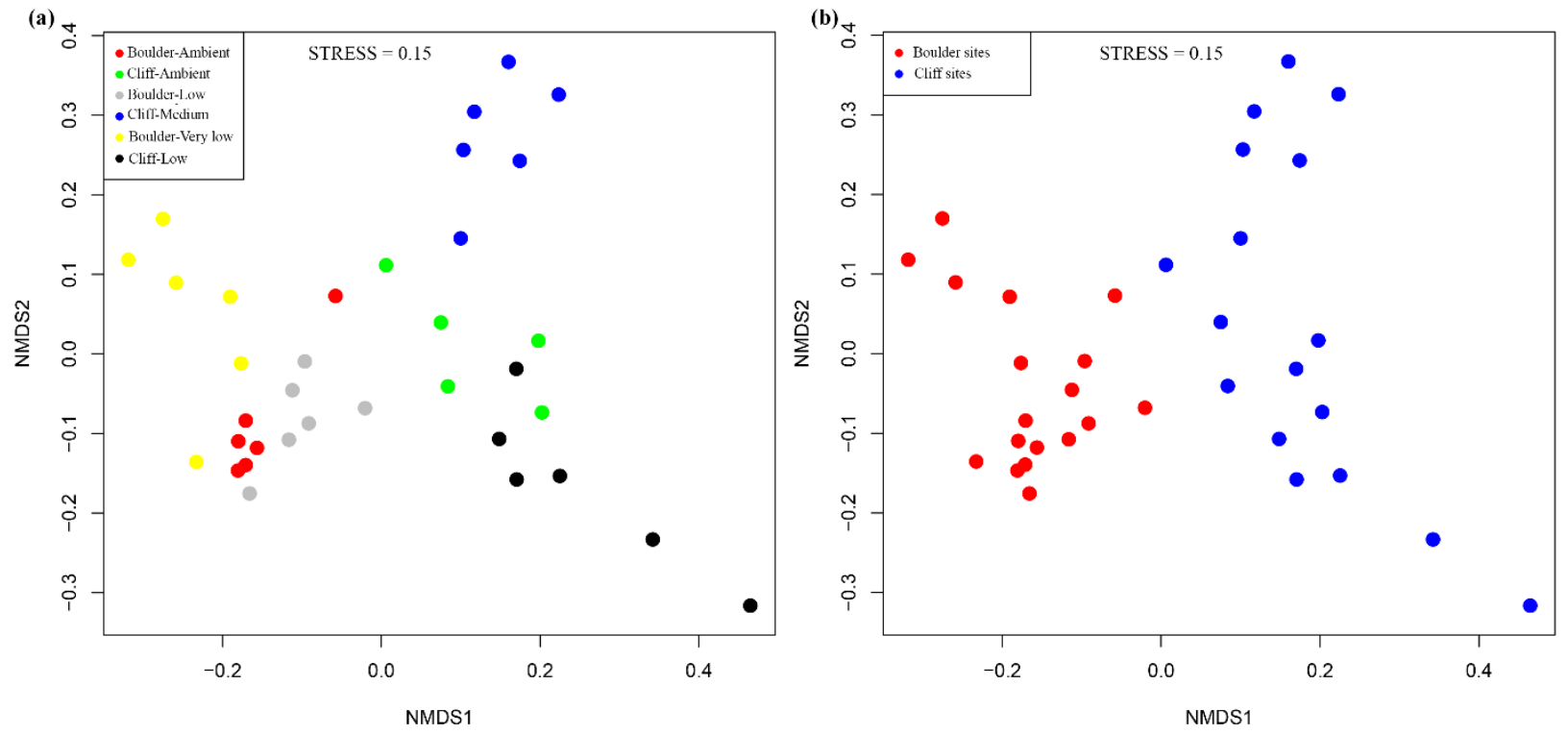

Fig. 4. NMDS ordination of total bacterial community composition among (a) different pH levels and (b) habitat types, based on BrayCurtis distance. 


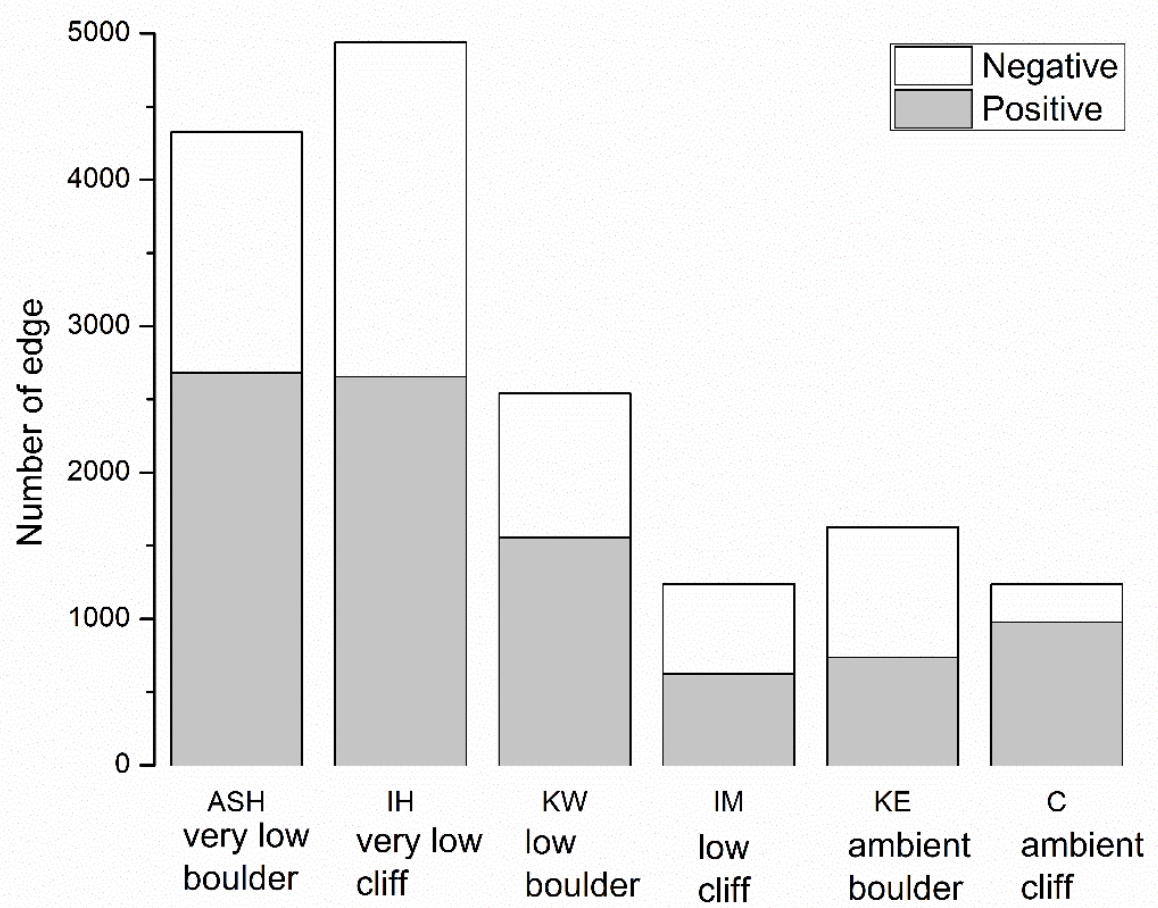

Fig. 5. Frequency of co-occurrence patterns of sampled stations. 


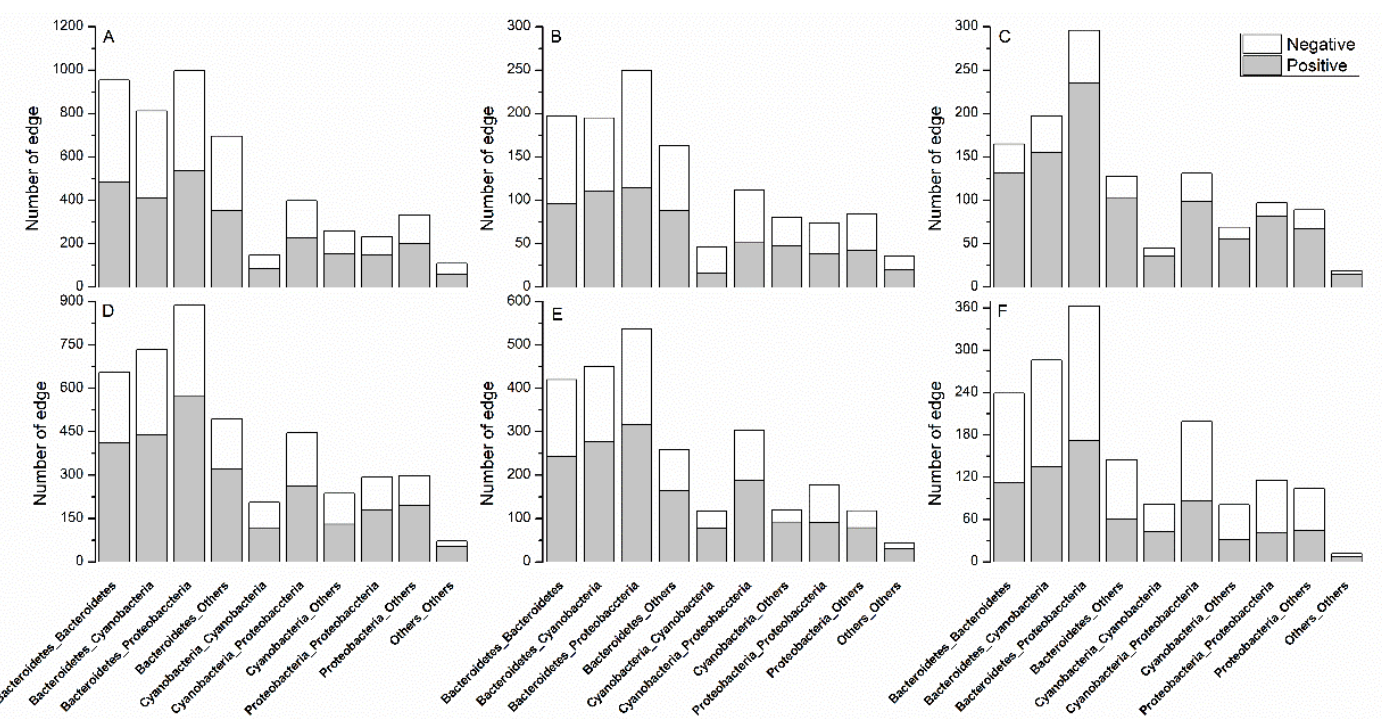

Fig. 6. Number of inter-Phylum and intra-Phylum co-presences and mutual exclusions of sampled stations (A: IH; B: IM; C: C; D: ASH; D: KW; F: KE). 

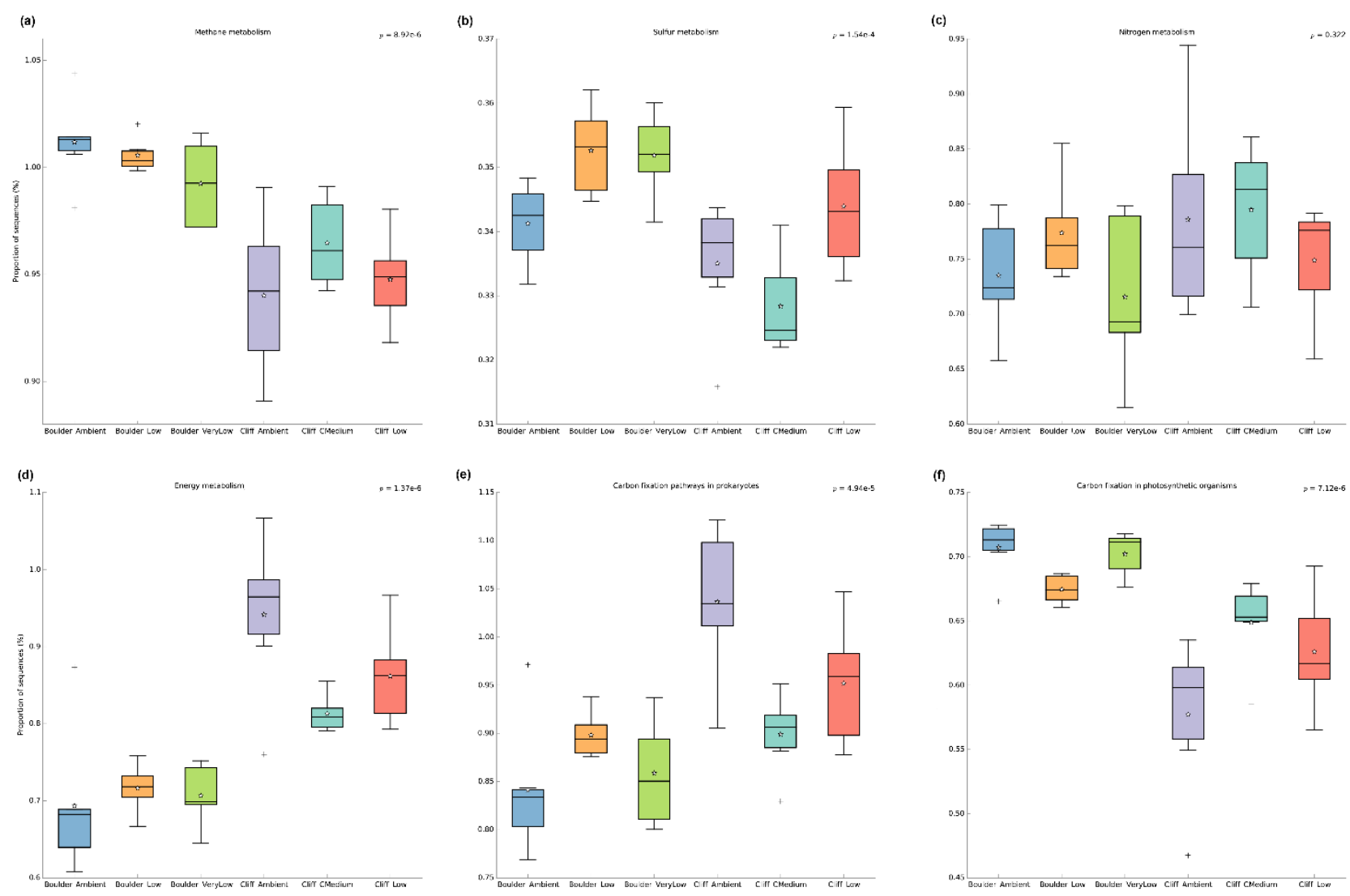

Fig. 7. Box plot representing the relative abundance of the (a) Methane metabolism, (b) Sulphur metabolism, (c) Nitrogen metabolism, (d) Energy metabolism, (e) Carbon fixation in Prokaryotes and (f) Carbon fixation in photosynthetic organisms. The analysis was based on KEGG module predictions using $16 \mathrm{~S}$ data with the software PICRUSt. Results from multiple group comparisons in function abundance (ANOVA, Tukey-Kramer, $P<0.05$ ) is reported as corrected $P$-value (Storey's FDR multiple test correction approach). The median value is shown as a line within the box and the mean value as a star. Error bars represent standard deviations. 
Table 1. Sea water chemistry across different sampling sites along $\mathrm{pH}$ gradient.

\begin{tabular}{|cccccccccccc}
\hline $\begin{array}{c}\text { Habitat } \\
\text { type }\end{array}$ & $\mathrm{pH}$ zone & $\begin{array}{c}\text { Salinity } \\
(\mathrm{psu})\end{array}$ & $\begin{array}{c}\mathrm{Temp} \\
\left({ }^{\circ} \mathrm{C}\right)\end{array}$ & $\begin{array}{c}\mathrm{A} \mathrm{T} \\
(\mu \mathrm{mol} \mathrm{kg})\end{array}$ & $\begin{array}{c}\mathrm{DIC} \\
\left(\mu \mathrm{mol} \mathrm{kg}{ }^{-1}\right)\end{array}$ & $\begin{array}{c}\mathrm{pH}_{\mathrm{NBS}} \\
p \mathrm{CO}_{2}\left(\mathrm{matm}^{-1}\right)\end{array}$ & $\begin{array}{c}\mathrm{HCO}_{3}{ }^{-} \\
\left(\mu \mathrm{mol} \mathrm{kg}^{-1}\right)\end{array}$ & $\begin{array}{c}\mathrm{CO}_{3}{ }^{2-} \\
\left(\mu \mathrm{mol} \mathrm{kg}^{-1}\right)\end{array}$ \\
\hline Boulder & Ambient & $34.0 \pm 0.1$ & $20.5 \pm 0.7$ & $2241.7 \pm 12.5$ & $1930.3 \pm 20.6$ & $8.28 \pm 0.03$ & $290.6 \pm 25.1$ & $1702.7 \pm 33.1$ & $218.3 \pm 13.4$ & $5.26 \pm 0.32$ & $3.42 \pm 0.21$ \\
Boulder & Low & $34.0 \pm 0.2$ & $20.4 \pm 0.7$ & $2201.4 \pm 57.0$ & $2141.5 \pm 23.9$ & $7.70 \pm 0.07$ & $1320.6 \pm 225.4$ & $2029.7 \pm 27.9$ & $69.4 \pm 11.3$ & $1.67 \pm 0.27$ & $1.09 \pm 0.18$ \\
Boulder & Very low & $34.1 \pm 0.1$ & $20.5 \pm 0.5$ & $2162.7 \pm 31.7$ & $2253.7 \pm 37.6$ & $7.24 \pm 0.10$ & $4003.9 \pm 877$ & $2100.2 \pm 16.0$ & $25.2 \pm 6.5$ & $0.61 \pm 0.16$ & $0.40 \pm 0.10$ \\
Cliff & Ambient & $34.0 \pm 0.0$ & $19.4 \pm 0.5$ & $2237.4 \pm 1.0$ & $1938.9 \pm 36.3$ & $8.27 \pm 0.06$ & $298.6 \pm 51$ & $1719.6 \pm 58.1$ & $209.4 \pm 23.5$ & $5.04 \pm 0.57$ & $3.27 \pm 0.37$ \\
Cliff & Medium & $34.0 \pm 0.1$ & $17.5 \pm 1.1$ & $2249.7 \pm 2.1$ & $2028.1 \pm 35.9$ & $8.15 \pm 0.07$ & $419.2 \pm 82.3$ & $1853.0 \pm 55.1$ & $160.5 \pm 22.4$ & $3.86 \pm 0.54$ & $2.49 \pm 0.35$ \\
Cliff & Low & $34.0 \pm 0.0$ & $18.5 \pm 0.7$ & $2281.7 \pm 31.3$ & $2186.8 \pm 82.4$ & $7.81 \pm 0.22$ & $1181.5 \pm 672.4$ & $2054.4 \pm 103.6$ & $92.3 \pm 42.1$ & $2.22 \pm 1.01$ & $1.44 \pm 0.66$ \\
\hline
\end{tabular}




\section{Supplementary Online Material}

\section{Responses of intertidal bacterial biofilm communities to increasing $p \mathrm{CO}_{2}$ in a naturally acidified system}

Dorsaf Kerfahi ${ }^{1}$, Ben Harvey ${ }^{2}$, Sylvain Agostini ${ }^{2}$, Koetsu Kon ${ }^{2}$, Ruiping Huang ${ }^{3}$, Jonathan M. Adams ${ }^{4 *}$, Jason M. Hall-Spencer ${ }^{2,5}$

${ }^{1}$ School of Applied Biosciences, College of Agriculture and Life Sciences, Kyungpook National University, Daegu, 41566, Republic of Korea.

${ }^{2}$ Shimoda Marine Research Center, University of Tsukuba, 5-10-1 Shimoda, Shizuoka, Japan.

${ }^{3}$ State Key Laboratory of Marine Environmental Science, Xiamen University, Xiamen, Fujian, 361100, China.

${ }^{4}$ School of Geographic and Oceanographic Sciences, Nanjing University, Nanjing 210008, China.

${ }^{5}$ School of Biological and Marine Sciences, University of Plymouth, Plymouth, PL4 8AA, United Kingdom.

*Corresponding author: Jonathan M. Adams.

School of Geographic and Oceanographic Sciences, Nanjing University, Nanjing 210008, China.

E-mail: foundinkualalumpur@yahoo.com 

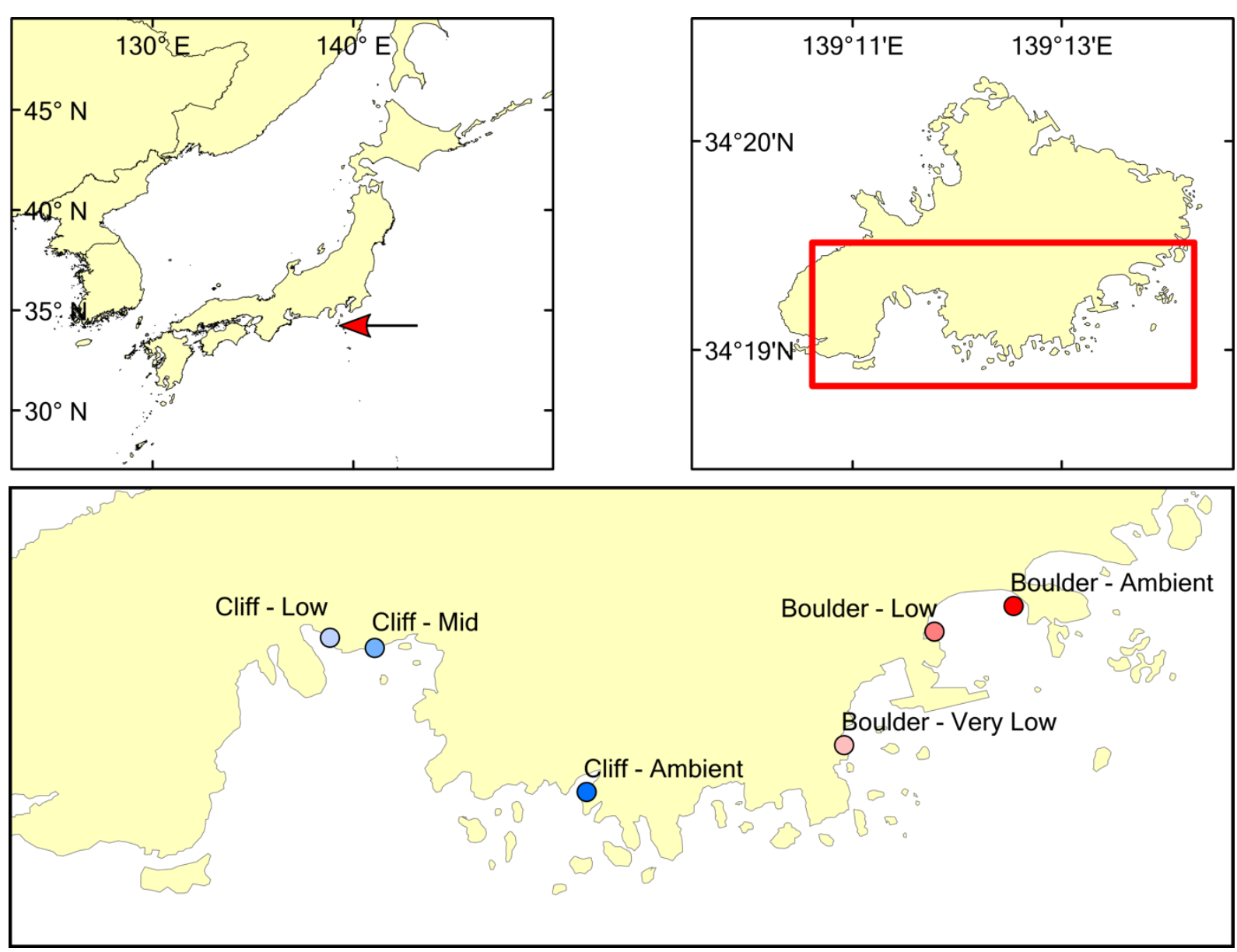

Fig. S1. Location of sample sites off Shikine Island, Japan. 


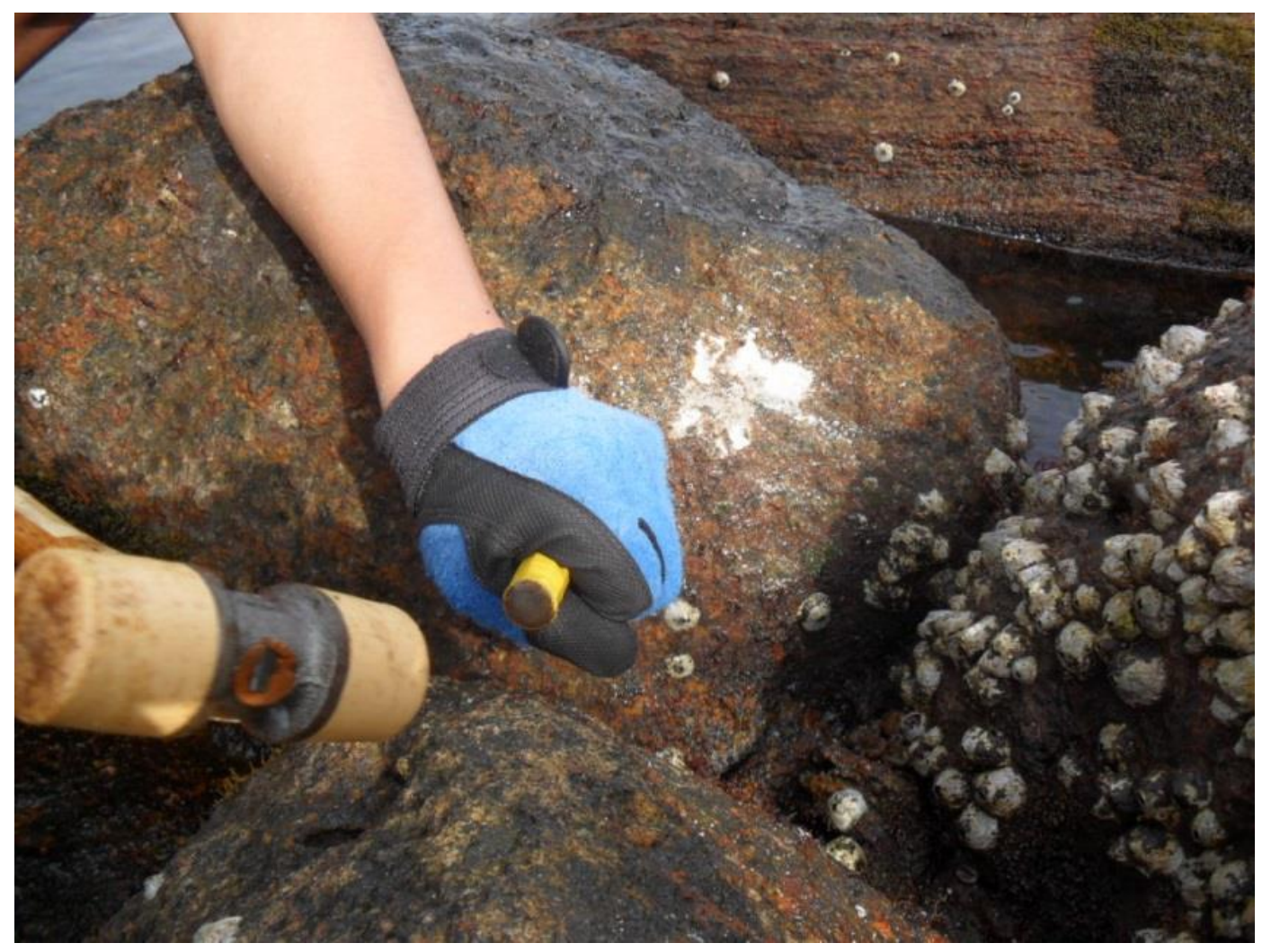

Fig. S2. Rock biofilm sampling along a pH gradient off Shikine Island, Japan. 


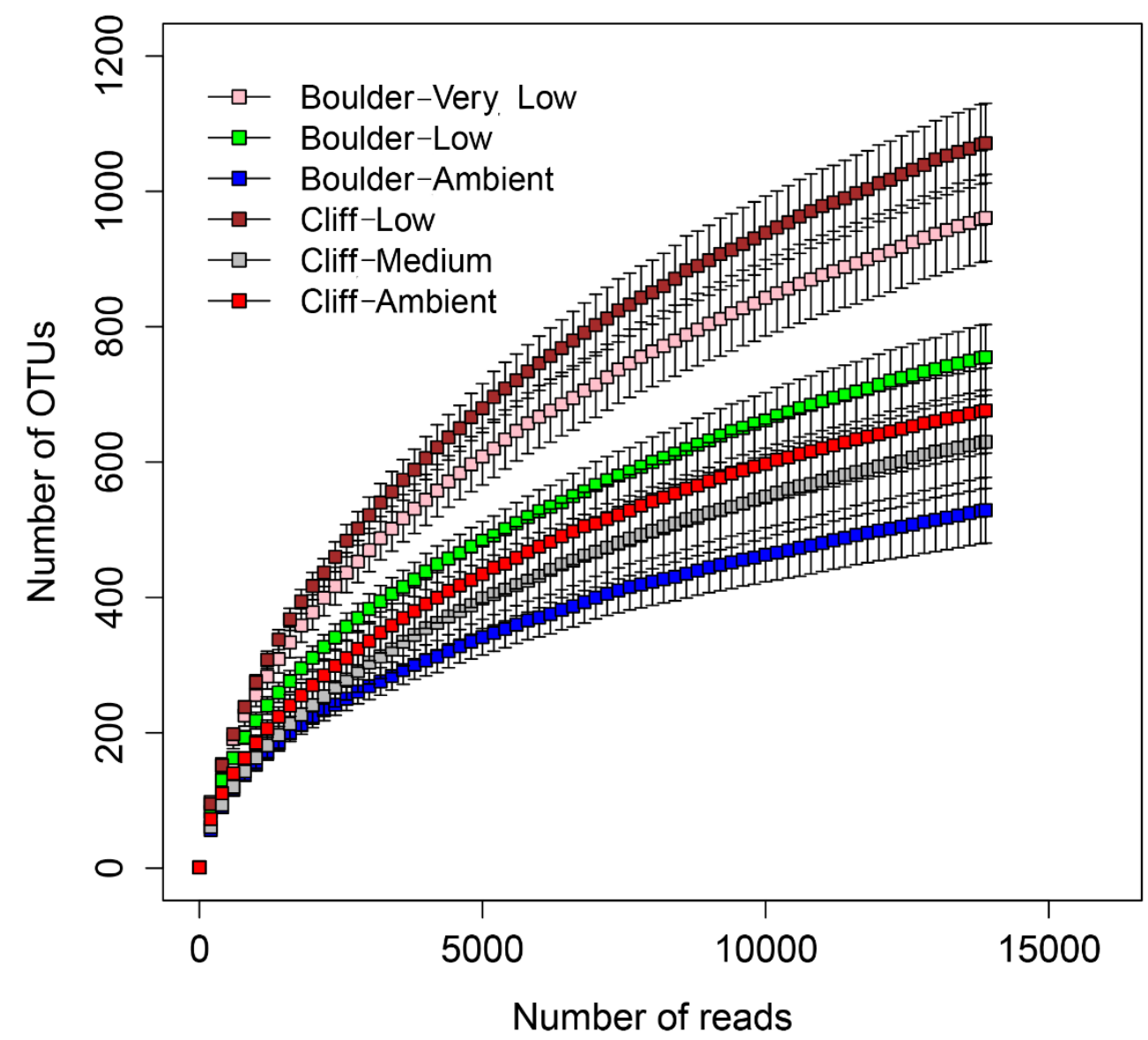

Fig. S3. Rarefaction curves comparing rock biofilm bacterial communities along a seawater pH gradient off Shikine Island, Japan. 
95\% confidence intervals

\section{Enzyme Families $\square$ \\ Environmental Adaptation | \\ Energy metabolism 日 \\ Function unknown \\ Digestive System |}

Membrane and intracellular structural molecules B

Metabolism of Cofactors and Vitamins

Circulatory System

Metabolic Diseases |

Inorganic ion transport and metabolism B

Energy Metabolism

Transcription

Neurodegenerative Diseases \

Other ion-coupled transporters 日

Transcription related proteins

Nucleotide metabolism | Others $\square$

Cell Growth and Death $日$

Carbohydrate metabolism \&

Nervous System |

Folding, Sorting and Degradation

$$
\text { Lipid Metabolism }
$$

Metabolism of cofactors and vitamins |

Transport and Catabolism B

Protein folding and associated processing 日

Amino Acid Metabolism

Cell Motility

Glycan biosynthesis and metabolism

Immune System Diseases

Replication and Repair

Replication, recombination and repair proteins $\square$

Carbohydrate Metabolism

$$
\text { Endocrine System } \mathrm{B}
$$

Biosynthesis of Other Secondary Metabolites $\mathrm{B}$

$$
\text { Immune System | }
$$

Metabolism of Terpenoids and Polyketides

Restriction enzyme |

Signaling Molecules and Interaction A

General function prediction only Sporulation |

Pores ion channels 日

Amino acid metabolism $\mathrm{B}$

Glycan Biosynthesis and Metabolism

Xenobiotics Biodegradation and Metabolism

Metabolism of Other Amino Acids

Translation

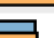

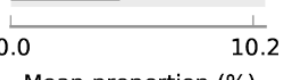

Mean proportion (\%)

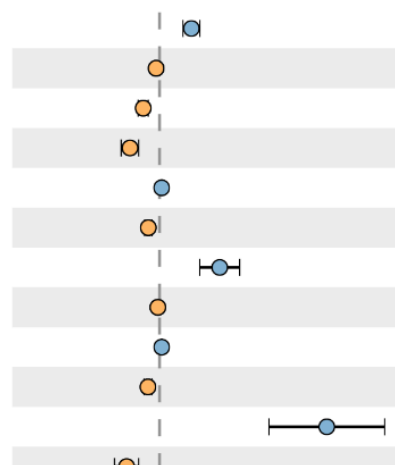

$1.18 \mathrm{e}-8$

4.83e-8

2.35e-7

$6.14 \mathrm{e}-7$

$1.06 \mathrm{e}-6$

$1.43 \mathrm{e}-6$

$1.62 \mathrm{e}-6$

$1.73 \mathrm{e}-6$

3.02e- 6

3.39e-6

3.84e- 6

$1.23 e-5$

1.32e-5

1.34e-5

2.31e-5

2.48e-5

3.49e-5

4.81e-5

5.30e-5

5.52e-5

$7.29 \mathrm{e}-5$

9.03e-5

$1.08 \mathrm{e}-4$

$1.97 \mathrm{e}-4$

$3.61 \mathrm{e}-4$ 궁

4.00e-4 ì

4.65e-4

5.19e-4

6.03e-4

6.53e-4

$1.07 \mathrm{e}-3$

$1.07 e-3$

$2.04 \mathrm{e}-3$

2.27e-3

3.22e-3

4.71e-3

9.77e-3

0.010

0.011

0.015

0.018

0.018

0.020

0.022

0.023

0.035

$\begin{array}{llllll}-1.5-1.0-0.50 .0 & 0.5 & 1.0 & 1.5 & 2.0 & 2.5\end{array}$

Difference in mean proportions (\%)

Fig. S4. Predicted differences in biofilm bacterial functional categories (PICRUSt) across

3 boulder and cliff sites off Shikine Island, Japan. 


\section{Responses of intertidal bacterial biofilm communities to increasing $\mathrm{pCO}_{2}$ in}

\section{6 a naturally acidified system}

7 Dorsaf Kerfahi ${ }^{1}$, Ben Harvey ${ }^{2}$, Sylvain Agostini ${ }^{2}$, Koetsu Kon ${ }^{2}$, Ruiping Huang ${ }^{3}$, Jonathan M.

8 Adams $^{4 *}$, Jason M. Hall-Spencer ${ }^{2,5}$

9

$10{ }^{1}$ School of Applied Biosciences, College of Agriculture and Life Sciences, Kyungpook 11 National University, Daegu, 41566, Republic of Korea.

12 Shimoda Marine Research Center, University of Tsukuba, 5-10-1 Shimoda, Shizuoka, Japan.

$13{ }^{3}$ State Key Laboratory of Marine Environmental Science, Xiamen University, Xiamen, 14 Fujian, 361100, China.

$15{ }^{4}$ School of Geographic and Oceanographic Sciences, Nanjing University, Nanjing 210008, 16 China.

$17{ }^{5}$ School of Biological and Marine Sciences, University of Plymouth, Plymouth, PL4 8AA, 18 United Kingdom.

$20 *$ Corresponding author: Jonathan M. Adams.

21 School of Geographic and Oceanographic Sciences, Nanjing University, Nanjing 210008, 22 China.

23 E-mail: foundinkualalumpur@yahoo.com 
Table S1. Results from two-way ANOVA showing the variation of the relative abundance of biofilm bacterial phyla across different sites.

\begin{tabular}{|c|c|c|c|c|c|}
\hline & & df & $\begin{array}{c}\text { Mean } \\
\text { square }\end{array}$ & $\begin{array}{c}\mathrm{F} \\
\text { model }\end{array}$ & P value \\
\hline \multirow[t]{3}{*}{ Cyanobacteria } & Habitat type & 1 & 5279 & 67.76 & $<0.001$ \\
\hline & $\mathrm{pH}$ & 2 & 234 & 3 & 0.064 \\
\hline & Habitat type * pH & 2 & 133 & 1.7 & 0.19 \\
\hline \multirow[t]{3}{*}{ Bacteroidetes } & Habitat type & 1 & 28.8 & 0.31 & 0.58 \\
\hline & pH & 2 & 451 & 4.85 & 0.01 \\
\hline & Habitat type * pH & 2 & 26.4 & 0.28 & 0.75 \\
\hline \multirow[t]{3}{*}{ Proteobacteria } & Habitat type & 1 & 5229 & 38.33 & $<0.001$ \\
\hline & $\mathrm{pH}$ & 2 & 134 & 0.98 & 0.38 \\
\hline & Habitat type * $\mathrm{pH}$ & 2 & 29 & 0.21 & 0.8 \\
\hline \multirow[t]{3}{*}{ Planctomycetes } & Habitat type & 1 & 5.81 & 12.48 & 0.001 \\
\hline & pH & 2 & 1.52 & 3.27 & 0.05 \\
\hline & Habitat type * pH & 2 & 3.67 & 7.9 & 0.001 \\
\hline \multirow{3}{*}{ Verrucomicrobia } & Habitat type & 1 & 1.5 & 1.58 & 0.21 \\
\hline & $\mathrm{pH}$ & 2 & 2.49 & 2.68 & 0.08 \\
\hline & Habitat type * pH & 2 & 4.38 & 4.61 & 0.01 \\
\hline \multirow[t]{3}{*}{ Chloroflexi } & Habitat type & 1 & 0.08 & 0.45 & 0.5 \\
\hline & $\mathrm{pH}$ & 2 & 0.38 & 2.09 & 0.14 \\
\hline & Habitat type * $\mathrm{pH}$ & 2 & 0.44 & 2.43 & 0.1 \\
\hline \multirow[t]{3}{*}{ Fusobacteria } & Habitat type & 1 & 1.04 & 0.96 & 0.33 \\
\hline & $\mathrm{pH}$ & 2 & 1.11 & 1.02 & 0.37 \\
\hline & Habitat type * pH & 2 & 1.06 & 0.97 & 0.38 \\
\hline \multirow[t]{3}{*}{ Acidobacteria } & Habitat type & 1 & 0.03 & 2.93 & 0.09 \\
\hline & $\mathrm{pH}$ & 2 & 0.02 & 1.72 & 0.19 \\
\hline & Habitat type * pH & 2 & 0.05 & 3.71 & 0.03 \\
\hline \multirow[t]{3}{*}{ Actinobacteria } & Habitat type & 1 & 0.0004 & 0.07 & 0.79 \\
\hline & $\mathrm{pH}$ & 2 & 0.009 & 1.47 & 0.24 \\
\hline & Habitat type * pH & 2 & 0.02 & 4.48 & 0.01 \\
\hline \multirow[t]{3}{*}{ Chlorobi } & Habitat type & 1 & 0.00005 & 0.02 & 0.8 \\
\hline & $\mathrm{pH}$ & 2 & 0.006 & 3.02 & 0.06 \\
\hline & Habitat type $* \mathrm{pH}$ & 2 & 0.001 & 0.52 & 0.59 \\
\hline \multirow[t]{3}{*}{ Gemmatimonadetes } & Habitat type & 1 & 0.001 & 2.58 & 0.11 \\
\hline & $\mathrm{pH}$ & 2 & 0.0009 & 1.7 & 0.19 \\
\hline & Habitat type * pH & 2 & 0.002 & 4.01 & 0.02 \\
\hline
\end{tabular}


Table S2. Results from two-way ANOVA showing the variation of the relative abundance of biofilm bacterial orders across different sites.

\begin{tabular}{|c|c|c|c|c|c|}
\hline & & $\mathrm{df}$ & $\begin{array}{l}\text { Mean } \\
\text { square }\end{array}$ & $\begin{array}{c}\mathrm{F} \\
\text { value }\end{array}$ & $\mathrm{P}$ value \\
\hline \multirow[t]{3}{*}{ Sphingobacteriales } & Habitat type & 1 & 95.67 & 1.49 & 0.23 \\
\hline & $\mathrm{pH}$ & 2 & 75.79 & 1.18 & 0.32 \\
\hline & Habitat type $* \mathrm{pH}$ & 2 & 159.8 & 2.49 & 0.09 \\
\hline \multirow[t]{3}{*}{ Flavobacteriales } & Habitat type & 1 & 11.9 & 0.31 & 0.57 \\
\hline & pH & 2 & 229 & 6.07 & 0.006 \\
\hline & Habitat type * pH & 2 & 634.8 & 16.8 & $<0.001$ \\
\hline \multirow[t]{3}{*}{ Oscillatoriales } & Habitat type & 1 & 191.7 & 9.89 & 0.003 \\
\hline & pH & 2 & 169.3 & 8.74 & 0.001 \\
\hline & Habitat type * pH & 2 & 127.9 & 6.60 & 0.004 \\
\hline \multirow[t]{3}{*}{ Pleurocapsales } & Habitat type & 1 & 2.56 & 0.07 & 0.78 \\
\hline & pH & 2 & 217.5 & 6.19 & 0.005 \\
\hline & Habitat type * pH & 2 & 109.4 & 3.11 & 0.05 \\
\hline \multirow[t]{3}{*}{ Vibrionales } & Habitat type & 1 & 1734.4 & 10.25 & 0.003 \\
\hline & $\mathrm{pH}$ & 2 & 16.7 & 0.09 & 0.90 \\
\hline & Habitat type $* \mathrm{pH}$ & 2 & 13.7 & 0.08 & 0.92 \\
\hline \multirow[t]{3}{*}{ Cytophagales } & Habitat type & 1 & 56.83 & 14.03 & $<0.001$ \\
\hline & pH & 2 & 18.16 & 4.48 & 0.01 \\
\hline & Habitat type * pH & 2 & 32.84 & 8.10 & 0.001 \\
\hline \multirow[t]{3}{*}{ Rhodobacterales } & Habitat type & 1 & 2.10 & 0.61 & 0.43 \\
\hline & $\mathrm{pH}$ & 2 & 1.11 & 0.32 & 0.72 \\
\hline & Habitat type * pH & 2 & 19.01 & 5.52 & 0.009 \\
\hline \multirow[t]{3}{*}{ Nostocales } & Habitat type & 1 & 228.1 & 15.25 & $<0.001$ \\
\hline & $\mathrm{pH}$ & 2 & 13.61 & 0.91 & 0.41 \\
\hline & Habitat type * pH & 2 & 38.75 & 2.59 & 0.09 \\
\hline \multirow[t]{3}{*}{ Alteromonadales } & Habitat type & 1 & 760.9 & 32.70 & $<0.001$ \\
\hline & pH & 2 & 106.3 & 4.56 & 0.01 \\
\hline & Habitat type * pH & 2 & 107 & 4.59 & 0.01 \\
\hline \multirow[t]{3}{*}{ Rhodospirillales } & Habitat type & 1 & 0.65 & 0.34 & 0.56 \\
\hline & $\mathrm{pH}$ & 2 & 4.84 & 2.58 & 0.09 \\
\hline & Habitat type * pH & 2 & 8.12 & 4.32 & 0.02 \\
\hline \multirow[t]{3}{*}{ Rhodothermus_o } & Habitat type & 1 & 6.38 & 32.18 & $<0.001$ \\
\hline & $\mathrm{pH}$ & 2 & 0.59 & 2.98 & 0.06 \\
\hline & Habitat type $* \mathrm{pH}$ & 2 & 0.44 & 2.22 & 0.12 \\
\hline \multirow[t]{3}{*}{ Rhizobiales } & Habitat type & 1 & 0.25 & 0.96 & 0.33 \\
\hline & pH & 2 & 1.64 & 6.17 & 0.005 \\
\hline & Habitat type * pH & 2 & 4.12 & 15.54 & $<0.001$ \\
\hline
\end{tabular}




\begin{tabular}{|c|c|c|c|c|c|}
\hline \multirow[t]{3}{*}{ Planctomycetales } & Habitat type & 1 & 2.80 & 9.29 & 0.004 \\
\hline & $\mathrm{pH}$ & 2 & 0.54 & 1.81 & 0.18 \\
\hline & Habitat type * pH & 2 & 2.27 & 7.53 & 0.002 \\
\hline \multirow[t]{3}{*}{ Verrucomicrobiales } & Habitat type & 1 & 1.45 & 1.51 & 0.22 \\
\hline & $\mathrm{pH}$ & 2 & 2.67 & 2.79 & 0.077 \\
\hline & Habitat type * pH & 2 & 8.31 & 4.34 & 0.022 \\
\hline \multirow[t]{3}{*}{ Phycisphaerales } & Habitat type & 1 & 0.25 & 5.86 & 0.02 \\
\hline & $\mathbf{p H}$ & 2 & 0.56 & 12.91 & $<0.001$ \\
\hline & Habitat type * pH & 2 & 0.16 & 3.72 & $\mathbf{0 . 0 3}$ \\
\hline \multirow[t]{3}{*}{ Kordiimonadales } & Habitat type & 1 & 3.02 & 4.21 & 0.04 \\
\hline & $\mathbf{p H}$ & 2 & 6.74 & 9.41 & $<0.001$ \\
\hline & Habitat type * pH & 2 & 2.31 & 3.22 & 0.05 \\
\hline \multirow[t]{3}{*}{ Parvularculales } & Habitat type & 1 & 0.08 & 2.61 & 0.11 \\
\hline & $\mathbf{p H}$ & 2 & 0.20 & 6.22 & 0.005 \\
\hline & Habitat type * pH & 2 & 0.004 & 0.13 & 0.87 \\
\hline \multirow[t]{3}{*}{ Balneola_o } & Habitat type & 1 & 1.64 & 3.78 & 0.06 \\
\hline & $\mathbf{p H}$ & 2 & 1.59 & 3.66 & 0.03 \\
\hline & Habitat type $*$ pH & 2 & 1.63 & 3.75 & $\mathbf{0 . 0 3}$ \\
\hline \multirow[t]{3}{*}{ Chromatiales } & Habitat type & 1 & 0.23 & 32 & $<0.001$ \\
\hline & $\mathbf{p H}$ & 2 & 0.05 & 6.96 & 0.003 \\
\hline & Habitat type * pH & 2 & 0.10 & 13.68 & $<0.001$ \\
\hline \multirow[t]{3}{*}{ Myxococcales } & Habitat type & 1 & 0.002 & 0.52 & 0.47 \\
\hline & $\mathbf{p H}$ & 2 & $\mathbf{0 . 0 3}$ & 7.74 & 0.001 \\
\hline & Habitat type $* \mathrm{pH}$ & 2 & 0.01 & 2.71 & 0.08 \\
\hline
\end{tabular}


Table S3. Results from two-way ANOVA showing the variation of the relative abundance of biofilm bacterial families across different sites.

\begin{tabular}{|c|c|c|c|c|c|}
\hline & & $\mathrm{df}$ & $\begin{array}{c}\text { Mean } \\
\text { square }\end{array}$ & $\begin{array}{c}\mathrm{F} \\
\text { value }\end{array}$ & $P$ value \\
\hline \multirow[t]{3}{*}{ Saprospiraceae } & Habitat type & 1 & 95.77 & 1.45 & 0.23 \\
\hline & $\mathrm{pH}$ & 2 & 76.24 & 1.18 & 0.31 \\
\hline & Habitat type * pH & 2 & 160 & 2.49 & 0.09 \\
\hline \multirow[t]{3}{*}{ Flavobacteriaceae } & Habitat type & 1 & 13.8 & 0.37 & 0.54 \\
\hline & $\mathbf{p H}$ & 2 & 220.3 & 5.94 & 0.006 \\
\hline & Habitat type ${ }^{*} \mathbf{p H}$ & 2 & 600.6 & 16.22 & $<0.001$ \\
\hline \multirow[t]{3}{*}{ Pleurocapsa family } & Habitat type & 1 & 2.53 & 0.07 & 0.79 \\
\hline & $\mathbf{p H}$ & 2 & 217.3 & 6.19 & 0.005 \\
\hline & Habitat type * pH & 2 & 109.4 & 3.11 & 0.05 \\
\hline \multirow[t]{3}{*}{ Vibrionaceae } & Habitat type & 1 & 1734.4 & 10.25 & 0.003 \\
\hline & $\mathrm{pH}$ & 2 & 16.7 & 0.09 & 0.90 \\
\hline & Habitat type $* \mathrm{pH}$ & 2 & 13.7 & 0.08 & 0.92 \\
\hline \multirow[t]{3}{*}{ Rivulariaceae } & Habitat type & 1 & 225.5 & 15.24 & $<0.001$ \\
\hline & $\mathrm{pH}$ & 2 & 12.13 & 0.82 & 0.45 \\
\hline & Habitat type $* \mathrm{pH}$ & 2 & 40.89 & 2.76 & 0.07 \\
\hline \multirow[t]{3}{*}{ Pseudoalteromonadaceae } & Habitat type & 1 & 508.4 & 22.64 & $<0.001$ \\
\hline & pH & 2 & 99.8 & 4.44 & 0.02 \\
\hline & Habitat type ${ }^{*} \mathbf{p H}$ & 2 & 99.7 & 4.44 & 0.02 \\
\hline \multirow[t]{3}{*}{ Rhodobacteraceae } & Habitat type & 1 & 1.49 & 1.41 & 0.24 \\
\hline & $\mathrm{pH}$ & 2 & 1.94 & 1.84 & 0.17 \\
\hline & Habitat type * pH & 2 & 5.21 & 4.94 & 0.01 \\
\hline \multirow[t]{3}{*}{ Porifericola family } & Habitat type & 1 & 10.50 & 11.31 & 0.002 \\
\hline & $\mathrm{pH}$ & 2 & 2.01 & 2.17 & 0.13 \\
\hline & Habitat type * pH & 2 & 4.26 & 4.59 & 0.01 \\
\hline \multirow[t]{3}{*}{ Hyphomonadaceae } & Habitat type & 1 & 0.05 & 0.04 & 0.83 \\
\hline & $\mathbf{p H}$ & 2 & 4.24 & 3.75 & 0.03 \\
\hline & Habitat type ${ }^{*} \mathbf{p H}$ & 2 & 4.42 & 3.91 & 0.03 \\
\hline \multirow[t]{3}{*}{ Planctomycetaceae } & Habitat type & 1 & 2.80 & 9.29 & 0.004 \\
\hline & $\mathrm{pH}$ & 2 & 0.54 & 1.081 & 0.18 \\
\hline & Habitat type ${ }^{*} \mathbf{p H}$ & 2 & 2.27 & 7.53 & 0.002 \\
\hline \multirow[t]{3}{*}{ Rubricoccus family } & Habitat type & 1 & 5.11 & 44.70 & $<0.001$ \\
\hline & $\mathrm{pH}$ & 2 & 0.22 & 1.96 & 0.15 \\
\hline & Habitat type * pH & 2 & 0.36 & 3.14 & 0.05 \\
\hline \multirow[t]{3}{*}{ Erythrobacteraceae } & Habitat type & 1 & 4 & 16.64 & $<0.001$ \\
\hline & $\mathbf{p H}$ & 2 & 0.94 & 3.94 & 0.03 \\
\hline & Habitat type $* \mathrm{pH}$ & 2 & 0.62 & 2.58 & 0.9 \\
\hline
\end{tabular}




\begin{tabular}{llcccc}
\hline Sphingomonadaceae & Habitat type & 1 & 0.28 & 1.41 & 0.24 \\
& pH & $\mathbf{2}$ & $\mathbf{0 . 7 3}$ & $\mathbf{3 . 6 7}$ & $\mathbf{0 . 0 3}$ \\
& Habitat type ${ }^{*} \mathbf{p H}$ & $\mathbf{2}$ & $\mathbf{2 . 2 3}$ & $\mathbf{1 1 . 1 2}$ & $<\mathbf{0 . 0 0 1}$ \\
\hline Planktothrix family & Habitat type & $\mathbf{1}$ & $\mathbf{1 4 . 4 2}$ & $\mathbf{1 5 . 0 6}$ & $<\mathbf{0 . 0 0 1}$ \\
& pH & $\mathbf{2}$ & $\mathbf{1 4 . 0 4}$ & $\mathbf{1 4 . 6 6}$ & $<\mathbf{0 . 0 0 1}$ \\
& Habitat type ${ }^{*} \mathbf{p H}$ & $\mathbf{2}$ & $\mathbf{1 2 . 0 1}$ & $\mathbf{1 2 . 5 4}$ & $<\mathbf{0 . 0 0 1}$ \\
\hline \multirow{2}{*}{ Alteromonadaceae } & Habitat type & $\mathbf{1}$ & $\mathbf{9 . 7 2}$ & $\mathbf{1 6 . 2 3}$ & $<\mathbf{0 . 0 0 1}$ \\
& pH & 2 & 0.36 & 0.61 & 0.54 \\
& Habitat type ${ }^{*} \mathrm{pH}$ & 2 & 0.45 & 0.75 & 0.47 \\
\hline Phycisphaeraceae & Habitat type & $\mathbf{1}$ & $\mathbf{0 . 1 2}$ & $\mathbf{4}$ & $\mathbf{0 . 0 5}$ \\
& pH & $\mathbf{2}$ & $\mathbf{0 . 2 0}$ & $\mathbf{6 . 7 2}$ & $\mathbf{0 . 0 0 3}$ \\
& Habitat type ${ }^{*}$ pH & 2 & 0.03 & 1.30 & 0.28 \\
\hline Flammeovirgaceae & Habitat type & $\mathbf{1}$ & $\mathbf{1 . 2 9}$ & $\mathbf{6 . 7 5}$ & $\mathbf{0 . 0 1}$ \\
& pH & $\mathbf{2}$ & $\mathbf{1 . 0 9}$ & $\mathbf{5 . 6 8}$ & $\mathbf{0 . 0 0 8}$ \\
& Habitat type ${ }^{*} \mathbf{p H}$ & $\mathbf{2}$ & $\mathbf{1 . 2 2}$ & $\mathbf{6 . 4 0}$ & $\mathbf{0 . 0 0 4}$ \\
\hline Alysiosphaera family & Habitat type & $\mathbf{1}$ & $\mathbf{0 . 3 2}$ & $\mathbf{6 . 4 5}$ & $\mathbf{0 . 0 1}$ \\
& pH & $\mathbf{2}$ & $\mathbf{0 . 2 8}$ & $\mathbf{5 . 6 1}$ & $\mathbf{0 . 0 0 8}$ \\
& Habitat type ${ }^{*} \mathbf{p H}$ & $\mathbf{2}$ & $\mathbf{0 . 3 9}$ & $\mathbf{7 . 9}$ & $\mathbf{0 . 0 0 1}$ \\
\hline Cohaesibacteraceae & Habitat type & $\mathbf{1}$ & $\mathbf{0 . 1 5}$ & $\mathbf{8 . 2}$ & $\mathbf{0 . 0 0 7}$ \\
& pH & 2 & 0.01 & 0.92 & 0.40 \\
& Habitat type $* \mathbf{p H}$ & $\mathbf{2}$ & $\mathbf{0 . 1 4}$ & $\mathbf{7 . 3 7}$ & $\mathbf{0 . 0 0 2}$ \\
\hline & & & & &
\end{tabular}


1 Table S4. Samples of "Boulder-Very low" and "Cliff-Ambient" sites formed the lowest nest while the 2 other samples are basically a subset of these.

\begin{tabular}{|c|c|}
\hline Group & Rank order of nestedness \\
\hline Boulder-Very low 1 & 16 \\
\hline Boulder-Very low 2 & 15 \\
\hline Boulder-Very low 3 & 3 \\
\hline Boulder-Very low 4 & 5 \\
\hline Boulder-Very low 5 & 23 \\
\hline Boulder-Very low 6 & 13 \\
\hline Cliff-Ambient 1 & 14 \\
\hline Cliff-Ambient 2 & 17 \\
\hline Cliff-Ambient 3 & 1 \\
\hline Cliff-Ambient 4 & 2 \\
\hline Cliff-Ambient 5 & 6 \\
\hline Cliff-Low 1 & 12 \\
\hline Cliff-Low 2 & 31 \\
\hline Cliff-Low 3 & 33 \\
\hline Cliff-Low 4 & 10 \\
\hline Cliff-Low 5 & 18 \\
\hline Cliff-Low 6 & 4 \\
\hline Cliff-Medium 1 & 25 \\
\hline Cliff-Medium 2 & 11 \\
\hline Cliff-Medium 3 & 7 \\
\hline Cliff-Medium 4 & 35 \\
\hline Cliff-Medium 5 & 32 \\
\hline Cliff-Medium 6 & 22 \\
\hline Boulder-Ambient 1 & 30 \\
\hline Boulder-Ambient 2 & 34 \\
\hline Boulder-Ambient 3 & 19 \\
\hline Boulder-Ambient 4 & 8 \\
\hline
\end{tabular}




\begin{tabular}{|l|r|}
\hline Boulder-Ambient 5 & 27 \\
\hline Boulder-Ambient 6 & 24 \\
\hline Boulder-Low 1 & 20 \\
\hline Boulder-Low 2 & 29 \\
\hline Boulder-Low 3 & 9 \\
\hline Boulder-Low 4 & 21 \\
\hline Boulder-Low 5 & 28 \\
\hline Boulder-Low 6 & 26 \\
\hline
\end{tabular}

3

4 